\title{
Geothermal fields of New Zealand in tourism industry - the case of complementary assets and competitive products
} Obszary geotermalne Nowej Zelandii jako obiekty turystyczne przykład komplementarności tematycznej i konkurencyjności produktu turystycznego

\author{
Edyta Pijet-Migoń ${ }^{1}$, Piotr Migoń ${ }^{2}$ \\ ${ }^{\prime}$ Wrockaw School of Banking, Institute of Tourism, \\ ul. Fabryczna 29-31, 53-609 Wroctaw; \\ e-mail:edyta.migon@wsb.wroclaw.pl \\ ${ }^{2}$ University of Wrocław, Institute of Geography and Regional Development, \\ pl. Uniwersytecki 1, 50-137 Wrocław; \\ e-mail:piotr.migon@uwr.edu.pl
}
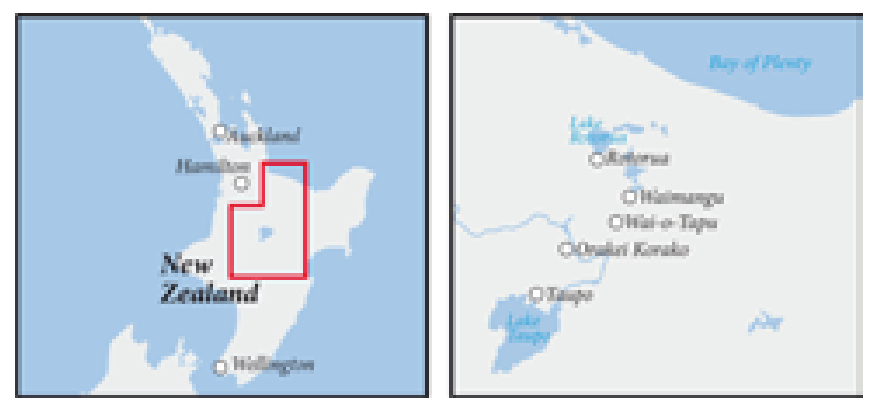

Abstract: Geothermal phenomena in the North Island of New Zealand have been a basis of tourism industry since the mid19th century. Their highlights include geysers, hot springs, mud pools, steam vents, craters, and various silica deposition features. Five geothermal sites, Te Puia Whakarewarewa, Waimangu, Wai-O-Tapu, Orakei Korako, and Craters of the Moon, are subjects of this study which is focused on interrelated issues of diversity, accessibility, and interpretation. The sites are sufficiently different in terms of natural phenomena to be perceived as complementary, offering jointly a comprehensive picture of geothermal phenomena. However, cooperation between their properties hardly exists. In promotion, unusual scenic values and record features are emphasized, whereas more in-depth interpretation is limited. There are opportunities to enhance educational components of each site, so that they can offer experience and learning rather than experience only and become fully developed geotourist destinations.

Key words: geothermal phenomena, interpretation, volcanic tourism, tourist product, tourism infrastructure, New Zealand

Treść: Zjawiska geotermalne na Wyspie Pótnocnej w Nowej Zelandii byly podstawa rozwoju turystyki na tym obszarze już od potowy XIX w. Szczególnym zainteresowaniem cieszyly się gejzery, gorace źródła, sadzawki błotne, fumarole i różnego rodzaju formy depozycyjne krzemionki. Do analizy form udostepniania dla zwiedzajacych oraz zagospodarowania pod katem edukacyjnym wybrano pięć popularnych miejsc geotermalnych: Te Puia Whakarewarewa, Waimangu, Wai-O-Tapu, Orakei Korako i Craters of the Moon. Miejsca te sa znacząco zróżnicowane pod względem przyrodniczym $i$ w sposób komplementarny przedstawiaja pełen obraz zjawisk geotermalnych, jednak pomiędzy tymi obiektami, zarzadzanymi przez różne przedsiębiorstwa, praktyczne nie ma wspótpracy. W promocji podkreślane sa głównie walory estetyczne tych miejsc, natomiast brakuje pogłębionej interpretacji prezentowanych zjawisk. Aby opisywane miejsca mogły oprócz przeżyć natury estetycznej dostarczać walorów edukacyjnych, a więc w petni spetniać kryteria atrakcji geoturystycznych, niezbędne jest rozszerzenie oferty umożliwiajacej interpretację zjawisk geotermalnych. Slowa kluczowe: zjawiska geotermalne, interpretacja, turystyka wulkaniczna, produkt turystyczny, zagospodarowanie turystyczne, Nowa Zelandia

\section{Introduction}

The issue of competition is at the core of the tourist industry and geotourism is not different in this respect. Whilst competition is most readily associated with service providers (accommodation, food, travel), sites of tourist interest compete too, particularly if they offer products and experience which are seemingly similar. In this paper we intend to examine this problem in respect to selected geothermal sites in the North Island of New Zealand, located between two renowned tourist destination cities - Rotorua and Taupo (Fig. 1). They are among the most visited in the country and offer an opportunity of close encountering with 'living Earth' in the form of geysers, mud pools, fumaroles, and hot springs (see also Latocha 2006; Roscoe, 2010). Thus, in terms of the main theme the geothermal sites of New Zealand are geotourist destinations, in fact ones of the most famous worldwide. They are also excellent illustrations of various issues related to the role played by volcanic and geothermal phenomena in tourism industry (Erfurt-Cooper, 2010, 2011, 2014).

The fame of the region dates back to the late $19^{\text {th }}$ century and travels to see geothermal phenomena, particularly geysers and silica terraces, are considered the beginning of international tourism in New Zealand (McClure, 2004). Nearly 150 years later, Rotorua maintains its strong position in both domestic and international tourist market of New Zealand, attracting c. 3.2 million visitors annually and offering a wide range of activities, among which sightseeing of geothermal sites occupies a very important place (Hall, Kearsley, 2001; Pearce, Tan, 2006). Today, nearly 10 geothermal sites have been developed as theme parks to cater for visitors. However, since they are located not far from each other (distance 
from Rotorua to Taupo is less than $100 \mathrm{~km}$, c. $1.5 \mathrm{hrs}$ drive) and the main theme is identical (at least for a person without strong interest in geosciences), tourists, especially international ones, often need to choose which localities to visit. How informed are their decisions and what can be expected at the sites themselves?



Fig. 1. Location map of geothermal tourist sites described in the paper • Mapa lokalizacyjna miejsc występowania zjawisk geotermalnych opisywanych w artykule

Research questions in the study carried out by the authors of this paper were:

- How the properties attempt to distinguish themselves in tourism destination marketing and which geothermal features are the main drawcards?

- How are they developed in terms of access, facilities, and environmental impact?

- How (if) an educational component of tourism is implemented? Are these sites merely scenic places or a more thorough understanding of geothermal phenomena is possible to achieve after the visit is completed? In other words, are they geotourist destinations in the sense of Hose (1995) who proposed that geotourism is 'the provision of interpretive and service facilities to enable tourists to acquire knowledge and understanding of the geology and geomorphology of a site (including its contribution to the development of the Earth sciences) beyond the level of mere aesthetic appreciation' (our italics)?
Therefore, apart from presentation of geothermal phenomena available for viewing, our study addresses two fields of interest: (a) marketing of tourist destinations with respect to geotourism, (b) educational component in geotourism. It also subscribes to a recent line of research at the interface between tourism and conservation (Hall, Lew, 2009), how to organize access to sites which are very special but also highly fragile or even dangerous. The latter issue is particularly relevant to volcanic tourism, which has great educational potential and can offer a truly unforgettable experience, but it also means an exposure of tourists to natural hazards and elevated risk (Erfurt-Cooper, 2011; Newhall, 2014). Indeed, hydrothermal eruptions are not uncommon on geothermal fields of New Zealand (Browne, Lawless, 2001) and occasionally caused fatalities among visiting tourists (Warbrick, 1934).

Five sites were selected for this study. Oriented from north to south, they are Te Puia Whakarewarewa in the city of Rotorua itself, Waimangu Volcanic Valley, Wai-O-Tapu, Orakei Korako, and Craters of the Moon. The sources of information used include on site observations, critical analysis of printed materials, analysis of properties' websites, and data contained in a popular visitor opinion website.

\section{Geothermal areas as hallmarks of New Zealand's tourism}

\section{Geological background}

Geothermal areas are those where Earth's heat flow towards the surface is elevated and therefore, the ground is warmer than elsewhere. They are typically connected with volcanic regions and usually the more active and recent the volcanism is, the more diverse and active are geothermal phenomena. Typical surface manifestations of geothermal activity are geysers, hot or even boiling springs and pools, fumaroles (steam vents), mud pools, and mud volcanoes. Secondary effects of hot water discharge include mineral precipitation (mostly silica) around the vents and along the path of water runoff. These sinter deposits can be very scenic, giving rise to cones, flats, cascades ('petrified waterfall'), terraces and raised rims around the springs. While precipitated silica is whitish, admixture of various other minerals and the presence of thermophilous algae may result in a range of colours. Another secondary effect is the origin of collapse craters, formed due to complete alteration and dissolution of rock underground due to contact with hot solutions. Occasionally, hydrothermal explosions may cause the origin of explosion craters. All these features are not only important from the scientific perspective, but they are also very scenic.

Geothermal fields of New Zealand are associated with the middle sector of the Taupo volcanic zone that runs SW-NE across the central-north part of the North Island (Fig. 1). They are arranged in 20 or so separate geothermal systems, spaced at quasi-regular intervals of 10-20 km (Hunt et al., 1994). Surface manifestations vary between separate systems, some being more evident and scenic than others. The long active 
systems are those in Rotorua, Wai-O-Tapu, and Orakei Korake and it is these localities where impressive sinter deposits occur. On the other hand, Waimangu in its present-day appearance is a very young system whose origin goes back to the eruption of Tarawera volcano in 1886 . However, the same eruption completely obliterated an older suite of geothermal features, centred around the Pink and White Terraces at Lake Rotomahana (Conly, 1985).

Geothermal fields are exploited for energy production and these industrial activities may severely interfere with the natural pace of heat release at the surface. In the study area the exploitation of geothermal field of Wairakei extinguished geysers near Craters of the Moon, while resulting in more activity of fumaroles. In Rotorua, a growing concern about the state of the geysers in the 1980s led to the closure of boreholes and many geysers have recovered since that time, but not all (Cody, Lumb, 1992; Scott et al., 2005).

\section{History of geothermal tourism}

Locations with particularly impressive geothermal phenomena, mainly geysers, fumaroles, and boiling mud pools, have attracted travellers since antiquity (e.g. solfatara fields at Campi Flegrei near Naples, Italy - Armiero et al., 2011) and more recently, they have developed into heavily visited and comprehensively managed tourist destinations (Erfurt-Cooper, 2010). Examples include the Yellowstone National Park in the United States, geyser fields of Iceland, and various localities across Japan. In this respect New Zealand is no different and geothermal features were the first to be exploited by tourism industry in this country (McClure, 2004).

The beginnings of tourism in the geothermal fields of New Zealand date back to the mid- $19^{\text {th }}$ century and are associated with the arrival of the first Europeans. In 1848 a missionary Seymour Mills Spencer built a mission station in Kariri, which was later moved to Te Wairoa, in the close proximity of White and Pink Terraces. The pioneer tourists to the area used the mission for accommodations . By 1895, three hotels offered accommodations in the vicinity of the terraces (Andrews, 1995).

The star attractions of the region - the White and Pink Terraces and most hot springs, mud pools and other geothermal phenomena - were located on Maori land. Thus, local people began to profit from emerging tourism, charging for entry permits, transportation (mainly by boat), and guiding. Guiding services were provided by a few individuals, mainly women. Little if any interpretation was available and storytelling was mainly restricted to various local legends (McClure, 2004). Undoubtedly, the petrified silica cascades at the Lake Rotomahana were the most famous natural site in the wider Rotorua area. The White and Pink Terraces were considered the 'eighth wonder of the world' and featured on sketches and paintings by visiting artists such as Charles Blomfield (Fig. 2), John Barr Clarke Hoyte and Charles Decimus Barraud, which made them even more famous (Conly, 1985). They also went into literature thanks to Anthony Trollope who described the terraces in his travel memories from
Australia and New Zealand (McClure, 2004). The images of White and Pink Terraces were present on postcards, holiday greeting cards and postal stamps. Another sign of their fame was an inclusion into catalogues and guidebooks published by the biggest contemporaneous tour-operator, Thomas Cook.

The early tourists usually divided their time spent in the Rotorua area into sightseeing focused on geothermal phenomena and hot spring bathing. Local Maori culture and traditions were additional attractions (Neilson et al., 2010). In 1870 the White and Pink Terraces and Rotorua hot springs were visited by Prince Alfred, a member of British Royal Family (Ell, 1995). His visit and shared impressions upon returning home prompted voices from aristocracy and politicians that geothermal fields of New Zealand should be purchased by the Crown from the Maori and become a property of the nation, similarly to the Yellowstone area in the United States (McClure, 2004). Simultaneously, an idea emerged to establish a to be world-famous spa in the Rotorua area, with legal foundations provided by the Thermal-Springs District Act approved by the parliament in 1881. Land purchases or lease from Maori commenced and the first 'Bath pavilion' allowing thermal bathing in sulphur-rich waters was opened in 1882. Three years later the first hospital (Sanatorium) available to all classes within the society started operations.

A violent explosion of the Tarawera volcano on 10 June 1886 was a blow to the growing tourism industry in the Rotorua region. Its direct consequences included disappearance of the White and Pink Terraces, origin of a string of new craters to the SE of Tarawera, burial of Te Wairoa village by volcanic ash, and destruction of existing tourist infrastructure (Andrews, 1995). At least 153 people lost their lives during the explosion (Ell, 1986). Fearing subsequent explosions and losing the main sight to visit, tourist were less keen to travel to Rotorua in the aftermath of the event. The number of visitors in 1887 decreased to 4878, in comparison with 6250 tourists the year before (McClure, 2004). However, interest soon revived and was further enhanced by the opening of a railway connection to Rotorua in 1894. In 1900 there were 5 hotels and 8 boarding houses catering to tourists in the town. The task to oversee the development of the area for tourism purposes was given to the governmental Department of Tourism and Health Resorts, considered the oldest ministry of tourism in the world (McClure, 2004).

Early $20^{\text {th }}$ century tourist visits to Rotorua included excursions to the buried village of Te Wairoa and to the Maori village of Whakarewarewa with its numerous hot springs, located a few kilometres south of Rotorua. Another, albeit short-lived attraction was the Waimangu geyser, active in 1900-1904, reputed to occasionally erupt to a height of 400 m (Houghton, Scott, 2008). In 1909 the number of visitors in Rotorua reached 9000, among them were approximately 4500 Australians and 2500 British (McClure, 2004). Since the 1920s the tourist product of Rotorua has become more diversified, but visiting geothermal phenomena remains the highlight of most trips (Ell, 1995; Ryan, Pike, 2003). 


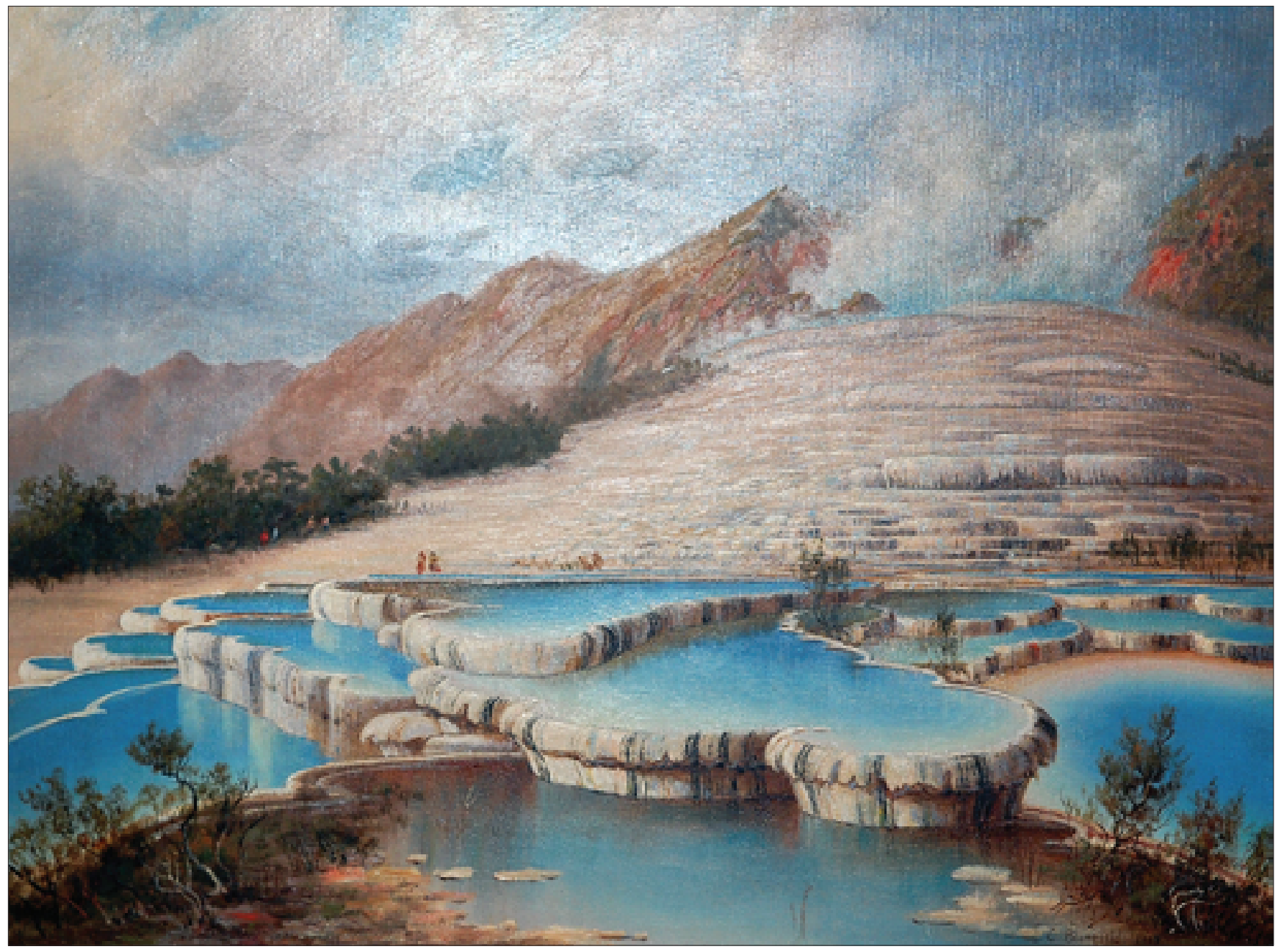

Fig. 2. White Terraces at Lake Rotomahana prior to the eruption of Tarawera volcano, painted by Charles Blomfield. Painting exhibited in the regional museum in Masterton, New Zealand, photo P. Migoń • „Białe tarasy” nad jeziorem Rotomahana przed erupcją wulkanu Tarawera na obrazie autorstwa Charlesa Blomfielda. Obraz wystawiony w muzeum regionalnym w Masterton, Nowa Zelandia, fot. P. Migoń

In 2013 c. 3.2 million travellers visited Rotorua, including 1.5 million staying overnight. The average length of a visit is 2.1 days. According to International Visitors Survey (www.tourismresearch.govt.nz, accessed 08.08.2015), approximately one third were international tourists and 87 per cent among them may be classified as 'Nature-based' tourists.

Tourism development further south was of later date and geothermal sites of Wai-O-Tapu and Orakei Korako became known tourist destinations in 1930s. At the former, a scenic reserve was established in 1931, the latter was officially opened in 1937. Craters of the Moon had long remained a freely accessible, but not developed site and its development for organized tourism occurred only in the 1990s. The town of Taupo, located closer to Orakei Korako and Craters of the Moon than Rotorua, is currently visited by c. 2 million tourists annually (www.med.govt.nz, accessed 08.08.2015), although the main reasons to come are water sports at Lake Taupo and various forms of adventure tourism.

\section{Study sites - geodiversity and additional values}

Below the key characteristics of geothermal sites are given, although the presentation is limited to parts developed for tourists. The main focus is on geothermal and related phenomena, but other values, both natural (plant communities) and cultural (Maori history, legacy of early tourism) are also indicated.

\section{Te Puia Whakarewarewa}

Whakarewarewa thermal area is situated at the southern outskirts of the city of Rotorua, c. $3 \mathrm{~km}$ from the city centre. From the accessibility perspective, the site is divided into two parts, each to be entered separately. Most of the terrain belongs to Te Puia Whakarewarewa and this is where the majority of geothermal phenomena occurs. The eastern part is occupied by the Whakarewarewa village which, although has a few hot pools and springs, is focused on Maori everyday life. Only features present at Te Puia are considered below. 
Geothermal phenomena are diverse and include hot springs, hot pools, vigorously boiling mud pools (Fig. 3), mud volcanoes, numerous fumaroles, sinter cones, and terraces of extinct geysers, but the highlight of the site is the group of active geysers overlooking the Puarenga stream, jointly sitting on the Geyser Flat (Lloyd, 1975). Two most famous ones are the Pohutu Geyser and the Prince of Wales Feathers Geyser. The former is reliably and regularly erupting with the typical frequency of 1-2 times per hour, usually to a height of 18-20 m (Fig. 4) (Houghton, Scott, 2008; Neilson et al., 2010).

Whilst geothermal phenomena are the highlights of $\mathrm{Te}$ Puia grounds, the property is also strongly focused on sustaining and promoting Maori traditions, especially art and craft. Schools of wood carving and weaving are part of the complex, there is a reconstructed ancient Maori village, and traditional Maori ceremonies are presented in the elaborately carved meeting house. In addition, the site hosts an educational nature trails with various native plants explained and a kiwi house, where these rare flightless birds can be observed.

\section{Waimangu Volcanic Valley}

Waimangu, located between Rotorua and Taupo (distances 24 and $50 \mathrm{~km}$ respectively), is a locality where geothermal phenomena are stretched along a SW-NE line of craters which opened up in June 1886, during the catastrophic eruption of the Tarawera volcano. A few subsequent hydrothermal eruptions occurred in the valley, notably in 1917 and 1973, but generally the area has recovered and become re-vegetated, offering now a range of geothermal phenomena amidst a green, forested valley and its steep sides (Fig. 5).

Among the craters two are particularly notable. The Frying Pan Lake fills the Echo Crater and occupying 3.8 ha is the world's largest hot spring, with a temperature around $50^{\circ} \mathrm{C}$ (Fig. 6) (Simmons et al., 2004). The nearby Inferno Crater is remarkable for its cyclic fluctuations of water level (over $8 \mathrm{~m}$ in c. 40 days) and temperature $\left(35-70^{\circ}\right)$ and hosts a geyser at the bottom. Other features include valley-floor silica terraces (Fig. 7), minor hot springs, steaming vents, and exposures of geothermally altered rocks. The site adjoins the Rotomahana Lake whose shores offer further examples of fumaroles and hot springs. In addition, several vantage points allow visitors to see wider panoramas of the area, including the Tarawera volcanic dome (Fig. 8).

The post-1886 eruption recovery of vegetation provides an opportunity to see many species of native flora, including ferns, kanuka, thermophilous mosses and algae. The site is also connected with Maori history and the history of tourism. Its heydays prior to 1886 , to see the Pink and White Terraces, and then in 1900-1904 to witness explosions of the Waimangu Geyser, are recalled on boards throughout the site.

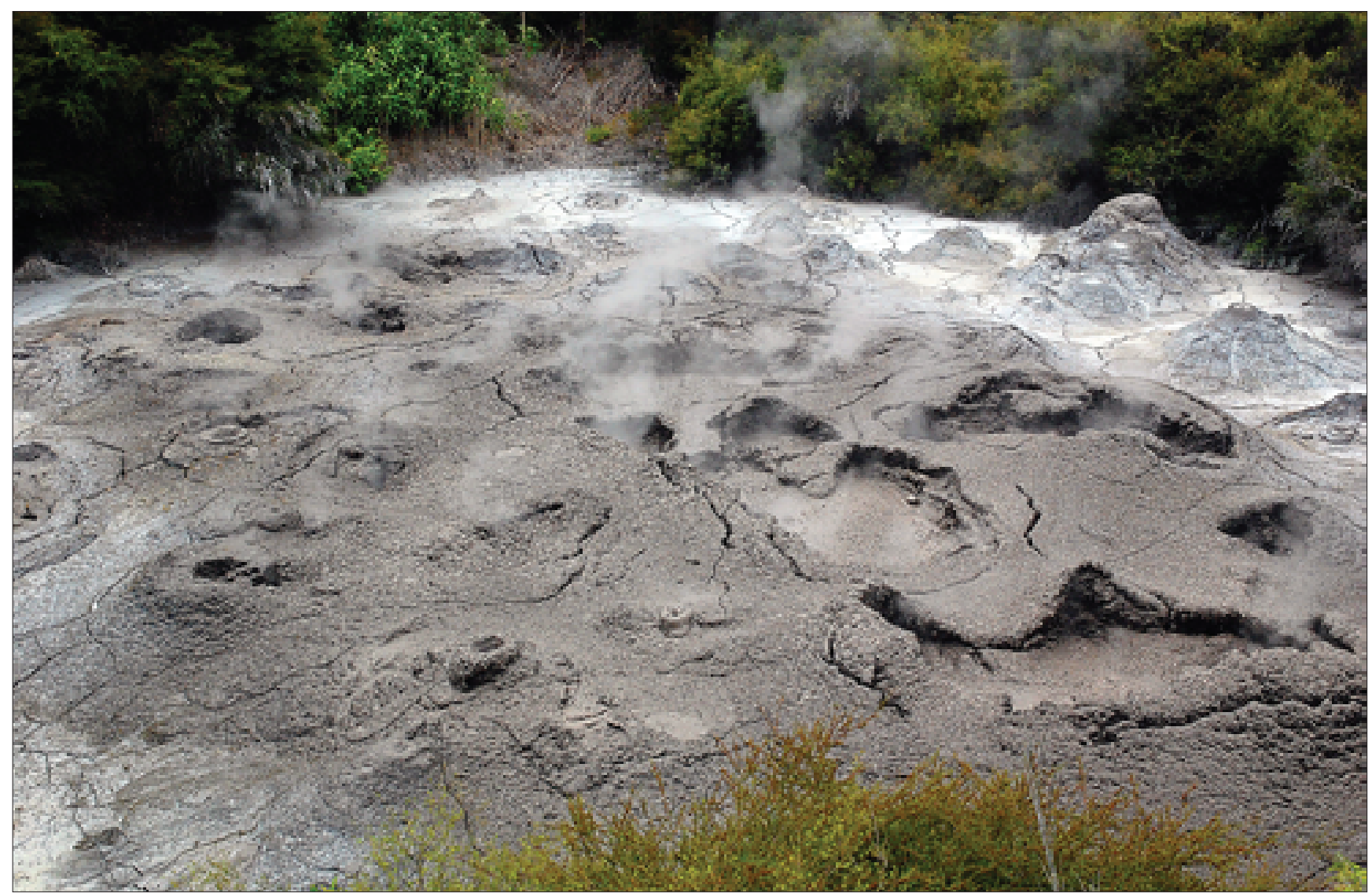

Fig. 3. Extremely active mud pool at Te Puia, Rotorua, photo P. Migoń • Wyjątkowo aktywna sadzawka błotna w Te Puia, Rotorua, fot. P. Migoń 


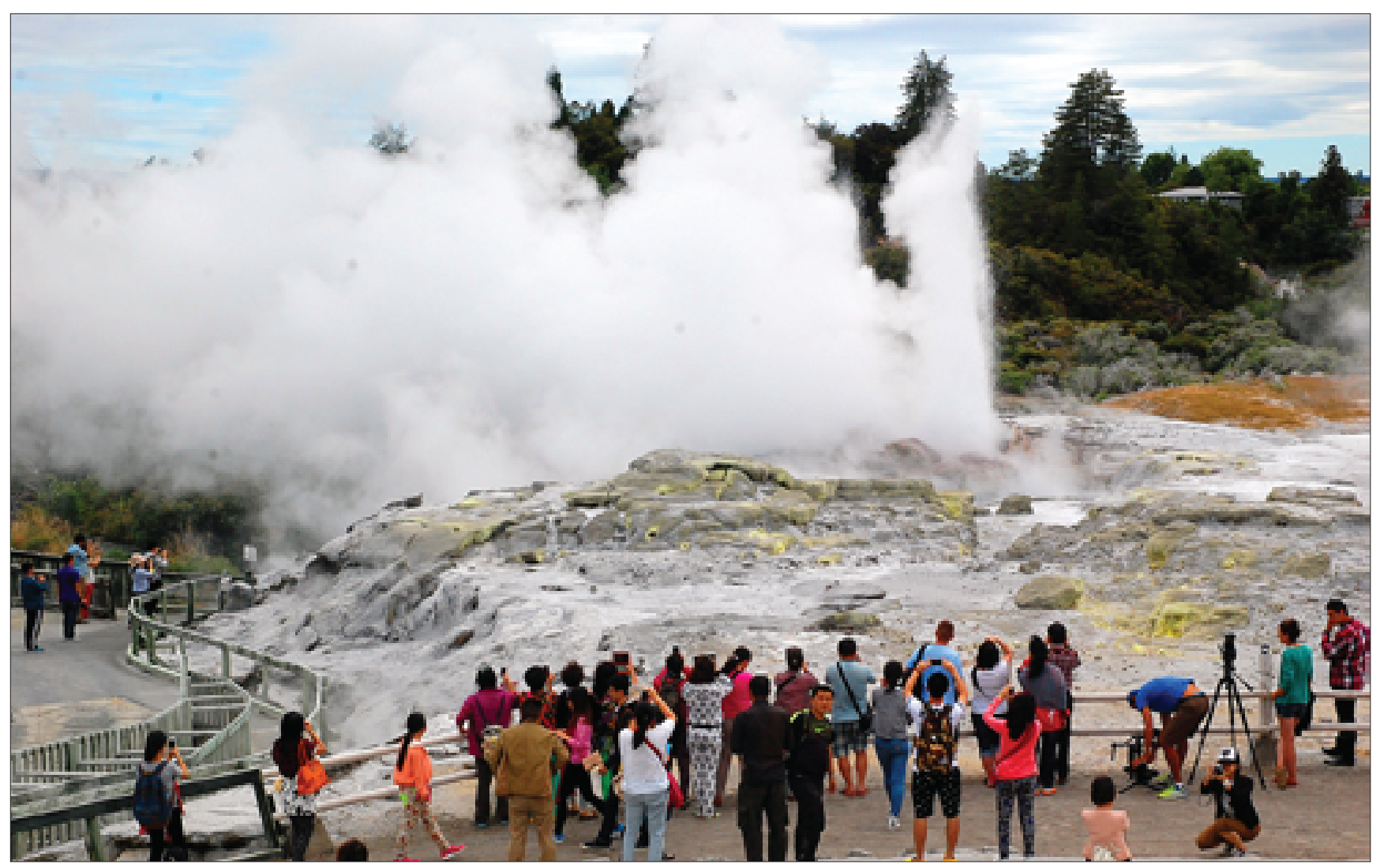

Fig. 4. Regular eruptions of the Pohutu Geyser are the main highlight of Te Puia geothermal site in Rotorua, photo P. Migoń • Regularne erupcje gejzeru Pohutu jako główna atrakcja stanowiska geotermalnego Te Puia w Rotorua, fot. P. Migoń

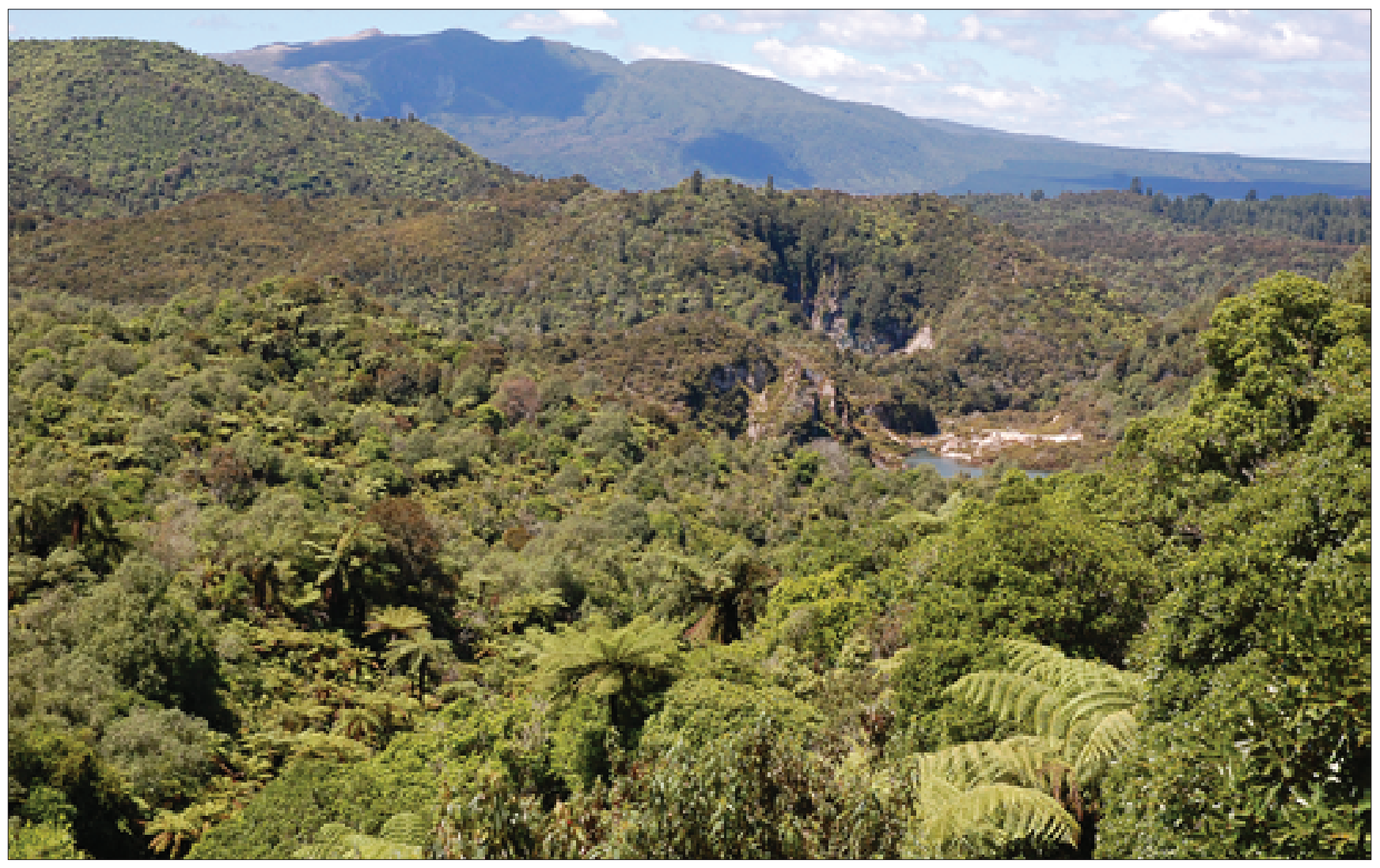

Fig. 5. Overview of Waimangu Volcanic Valley. Echo Crater with Frying Pan Lake in the lower right, with Inferno Crater above. The background of the scene is provided by the Tarawera volcano that violently erupted in June 1886, photo P. Migoń - Ogólny widok wulkanicznej doliny Waimangu. Echo Crater z jeziorem Frying Pan u dołu po prawej, krater Inferno znajduje się powyżej. Na ostatnim planie wulkan Tarawera, słynny z potężnej eksplozji w czerwcu 1886 r., fot. P. Migoń 




Fig. 6. Frying Pan Lake in Waimangu Volcanic Valley, with cliffs of Cathedral Rocks in the background, photo P. Migoń • Gorące jezioro Frying Pan w wulkanicznej dolinie Waimangu, z urwiskami Cathedral Rocks w tle, fot. P. Migoń

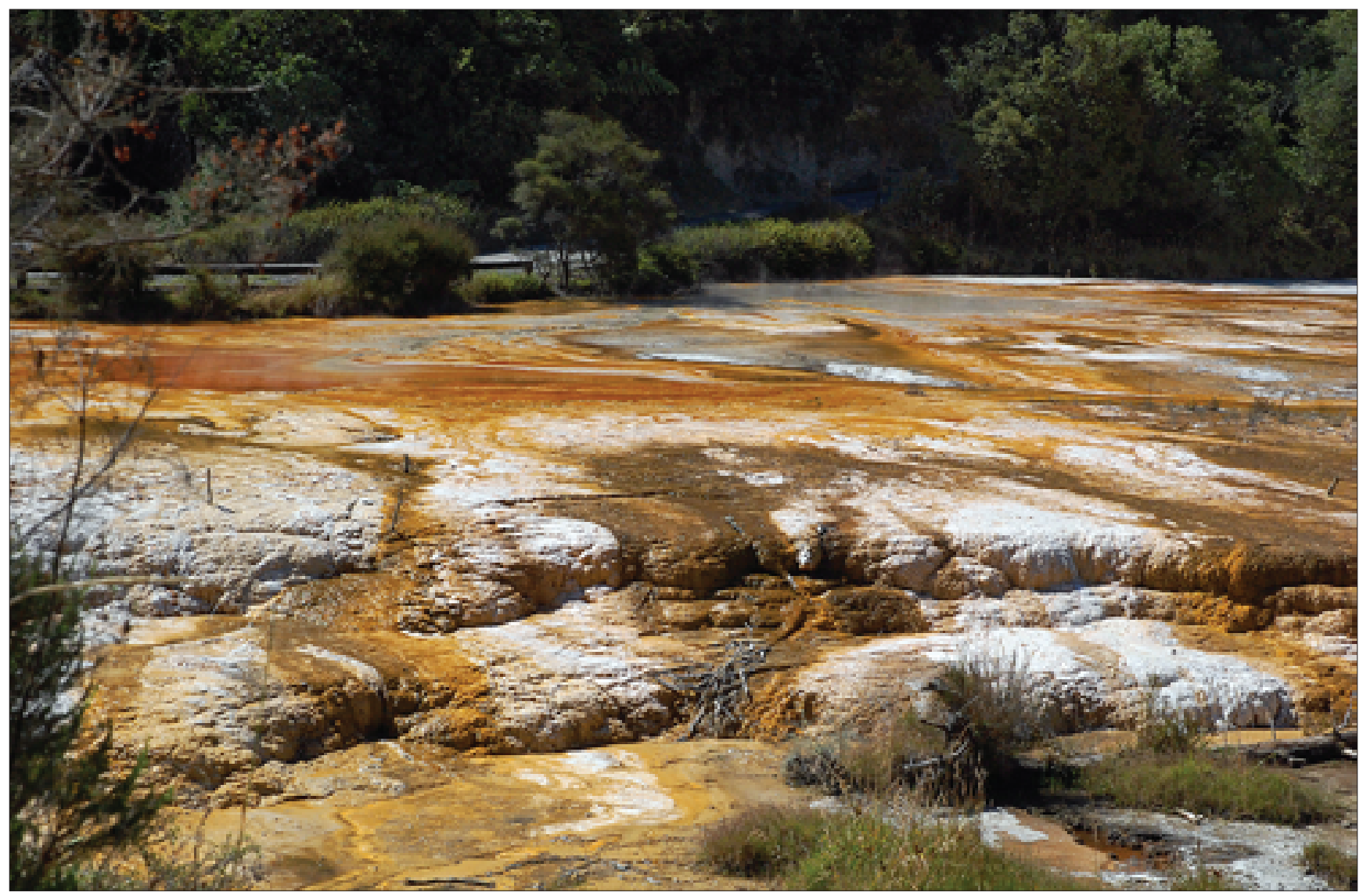

Fig. 7. Valley floor silica terraces in Waimangu Volcanic Valley, photo P. Migoń • Terasy krzemionkowe w dnie doliny w wulkanicznej dolinie Waimangu, fot. P. Migoń 


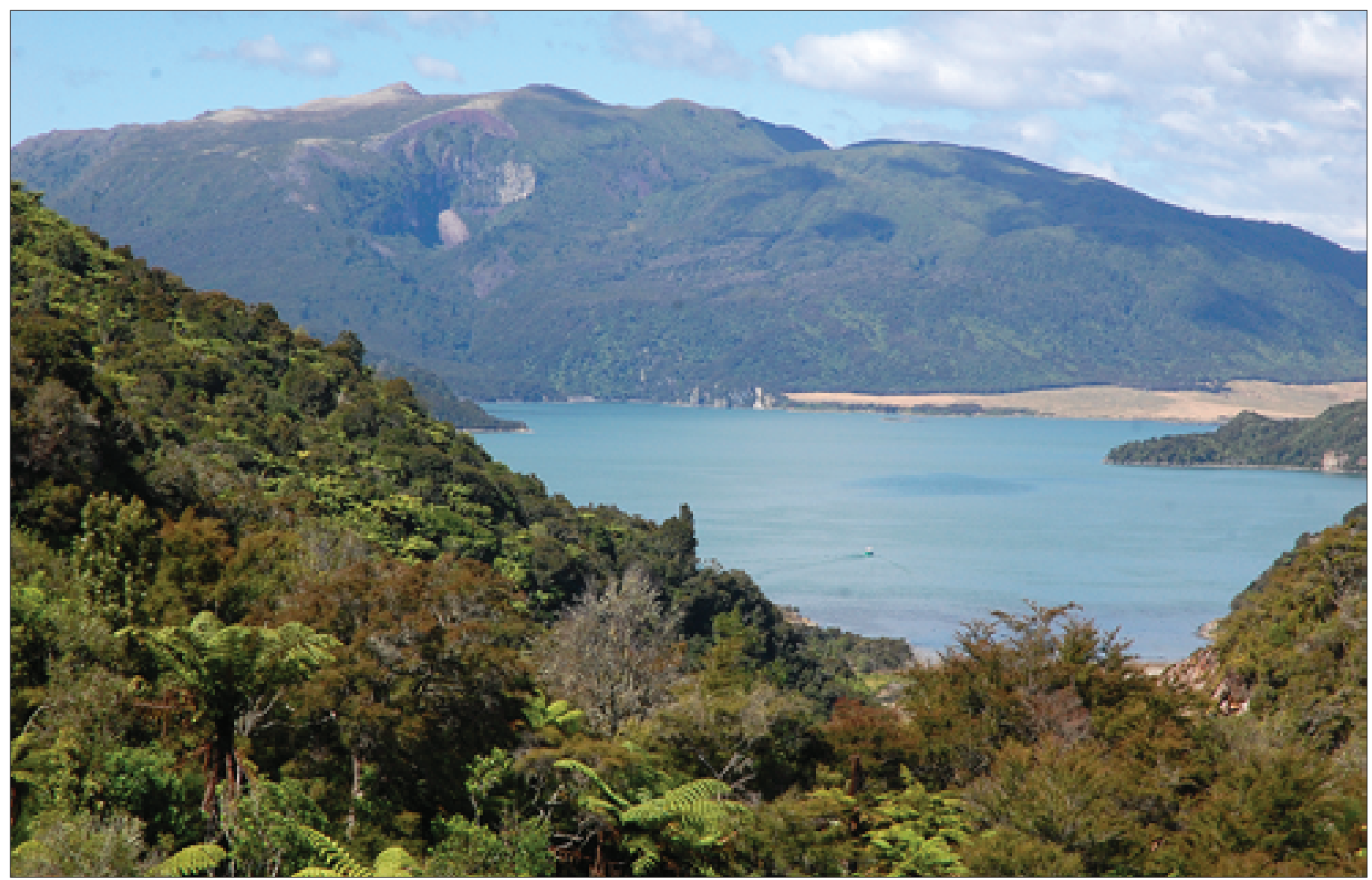

Fig. 8. Lake Rotomahana and the dome of Tarawera volcano in the background. Remnants of White and Pink Terraces have been found on the lake bottom, photo P. Migoń - Jezioro Rotomahana i kopuła wulkanu Tarawera w tle. Pozostałości Białych i Różowych Tarasów zostały odnalezione na dnie jeziora, fot. P. Migoń

\section{Wai-O-Tapu}

Wai-O-Tapu is located not far from Waimangu, $8 \mathrm{~km}$ to the south (27 km from Rotorua). The entire geothermal field occupies c. $18 \mathrm{~km}^{2}$ (Lloyd, 1959), but only a fraction has been developed for tourism. The property actually consists of three separate sites. The largest and most diverse is WaiO-Tapu itself, approximately $0.8 \mathrm{~km}$ long and $0.2 \mathrm{~km}$ wide. Informally it can be divided into three parts. The northern one is typified by a high density of collapse craters, including spectacular Rainbow Crater, Devil's Bath, and Devil's Ink Pots (Fig. 9).

Craters are $10-50 \mathrm{~m}$ across and up to $10 \mathrm{~m}$ deep, some with pools of boiling muddy waters in the bottom. The highlight of the central part is the Champagne Pool - the largest hot spring $\left(\mathrm{c} .74^{\circ} \mathrm{C}\right)$ in the area, distinguished by its raised rims and underwater orange-coloured benches (Fig. 10). The pool is $65 \mathrm{~m}$ across and $62 \mathrm{~m}$ deep. Next to it a long 'silica river' starts, initially nearly $100 \mathrm{~m}$ wide, but narrowing down to $15 \mathrm{~m}$ at the end, some $250 \mathrm{~m}$ away. At the lower end of the site a maze of old explosion craters occurs, partly filled with water and partly occupied by mud flats and mud craters (Fig. 11).

Approximately $1 \mathrm{~km}$ to NE is the site of Lady Knox Geyser whose regular eruptions at 10:15 am (Fig. 12) are artificially induced by adding soap. The geyser itself was created artificially, by inserting a pipe into a vent of a hot spring that occurred in this place prior to the early $20^{\text {th }}$ century (Houghton,
Scott, 2008). Over the years a $1.5 \mathrm{~m}$ high sinter cone has built up around the geyser exit and a silica pedestal extends around. The third site, although in contrast to the other two with free access, is a large and extremely active mud pool (Fig. 13) that occupies a site of a former mud volcano that was destroyed by erosion around 1925 (Houghton, Scott, 2008).

\section{Orakei Korako}

Orakei Korako is located on the east bank of an artificial Ohakuri Lake which flooded a section of the Waikato river valley, approximately $20 \mathrm{~km}$ north of Taupo (Lloyd, 1972). Geothermal phenomena are associated with voluminous outflows of silica-laden thermal waters, from which silica precipitates to form flats, miniature terraces, cascades, and steps up to $5 \mathrm{~m}$ high (Fig. 14). The latter are sinter-covered fault scarps formed during an earthquake, probably at some time in $2^{\text {nd }}$ century AD (Fig. 15). The total length of the silica 'river' is nearly $400 \mathrm{~m}$, with width varying from 30 to $80 \mathrm{~m}$. These sinter cascades are considered the largest features of this kind in New Zealand (Fig. 16), after the Pink and White Terraces were destroyed in 1886. Further points of interest include geyser-like eruptions, hot spring and pools, active (albeit small) mud volcanoes, and the Ruatapu cave, $45 \mathrm{~m}$ long and $23 \mathrm{~m}$ deep, which is the only cave genetically connected with hydrothermal processes in New Zealand (Rodgers et al., 2000). The central 'silica' river is surrounded by lush native forest through which the loop trail goes. 


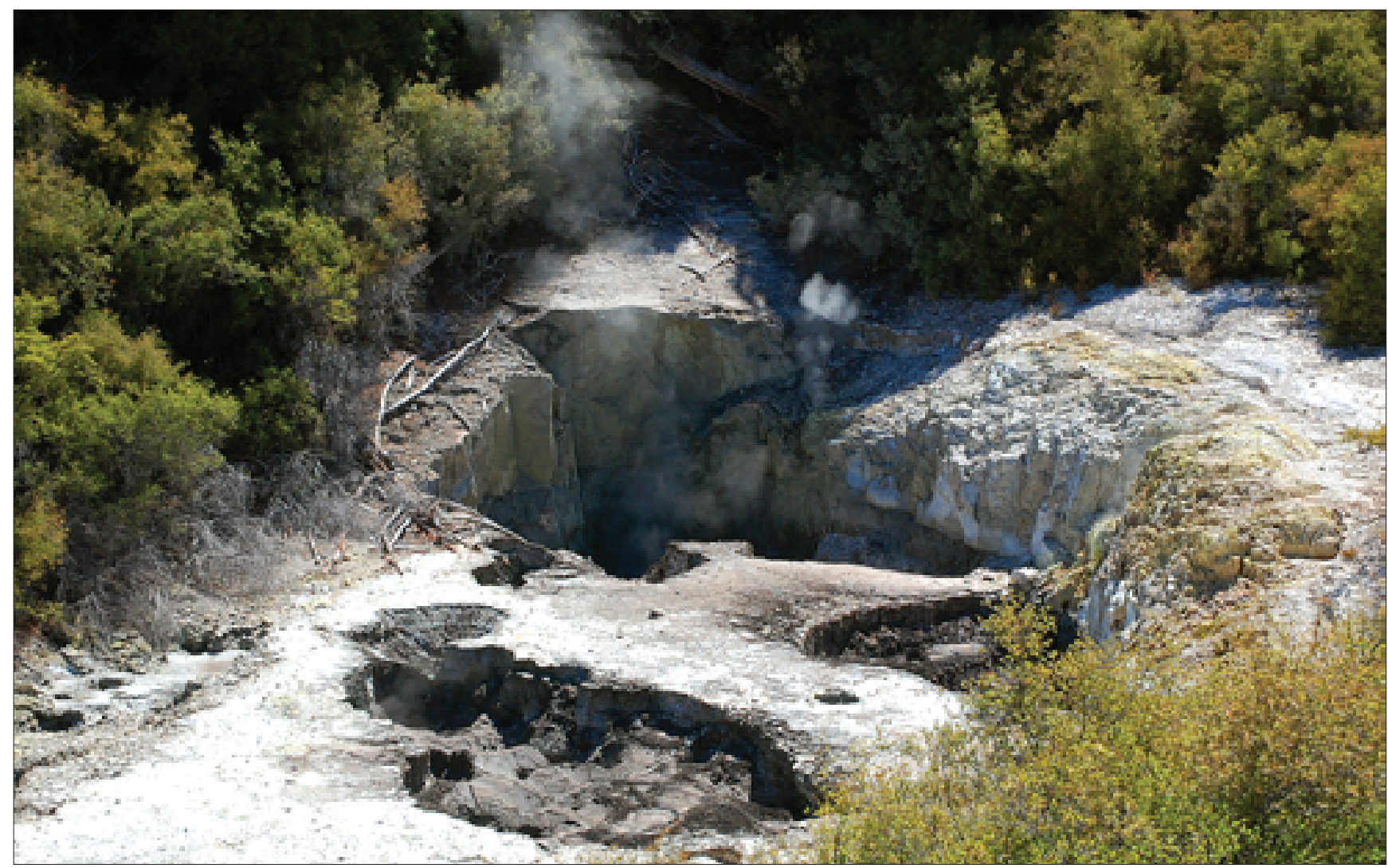

Fig. 9. Devil's Ink Pot - a group of hydrothermal explosion craters at Wai-O-Tapu, photo P. Migoń • "Kałamarze Diabła" - grupa hydrotermalnych kraterów eksplozywnych w Wai-O-Tapu, fot. P. Migoń

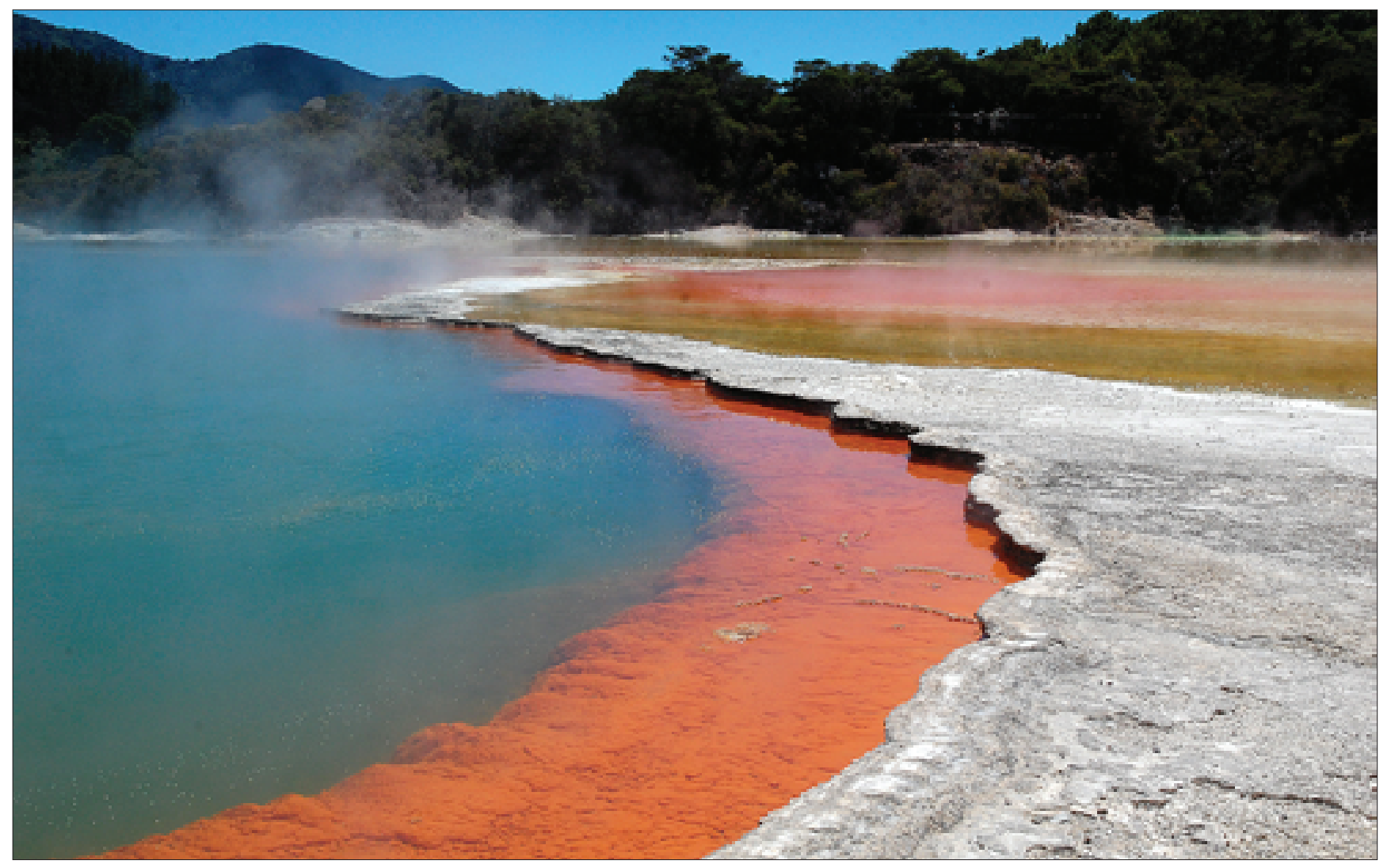

Fig. 10. Raised silica rims along the hot spring of Champagne Pool, Wai-O-Tapu, photo P. Migoń • Podwyższone krawędzie utworzone przez osad krzemionkowy wokół gorącego źródła Champagne Pool w Wai-O-Tapu, fot. P. Migoń 



Fig. 11. General view of the lower part of Wai-O-Tapu property, with craters left by prehistoric hydrothermal explosions, photo P. Migoń - Widok ogólny dolnej części obszaru geotermalnego Wai-O-Tapu z kraterami będącymi pozostałością po prehistorycznych erupcjach hydrotermalnych, fot. P. Migoń

Fig. 12. Lady Knox Geyser during artificially induced eruption, photo P. Migoń - Gejzer Lady Knox podczas sztucznie wywołanej erupcji, fot. P. Migoń

\section{Craters of the Moon}

Craters of the Moon is the smallest among geothermal, tourist-developed sites considered in this paper. It is located approximately $4 \mathrm{~km}$ north of the centre of Taupo. Geothermal phenomena have developed within a shallow, nearly circular basin, c. $0.7 \mathrm{~km}$ across (Fig. 17). This locality used to show very little activity prior to 1950 s, but the industrial development of the Wairakei geothermal power plant and increasing exploitation of geothermal heat through many boreholes resulted in a change of hydrogeological conditions at depth, cessation of geyser activity in the surroundings, and the appearance of multiple fumaroles and steaming vents.

Nowadays the key natural features of Craters of the Moon are three large compound craters 50-90 $\mathrm{m}$ across and up to $10 \mathrm{~m}$ deep. Besides, one can see inactive and partially collapsed large craters (Fig. 18), numerous smaller ground depressions (c. $10 \mathrm{~m}$ long) with steam emissions, ground cracks, and hydrothermally altered colourful rock outcrops. Thermophilous mosses and ferns occupy the site, which also hosts blankets of hot temperature adapted prostrate kanuka. 




Fig. 13. Mud ejections at Mud Pool, Wai-O-Tapu, photo P. Migoń - Wyrzuty błota w Mud Pool, Wai-O-Tapu, fot. P. Migoń

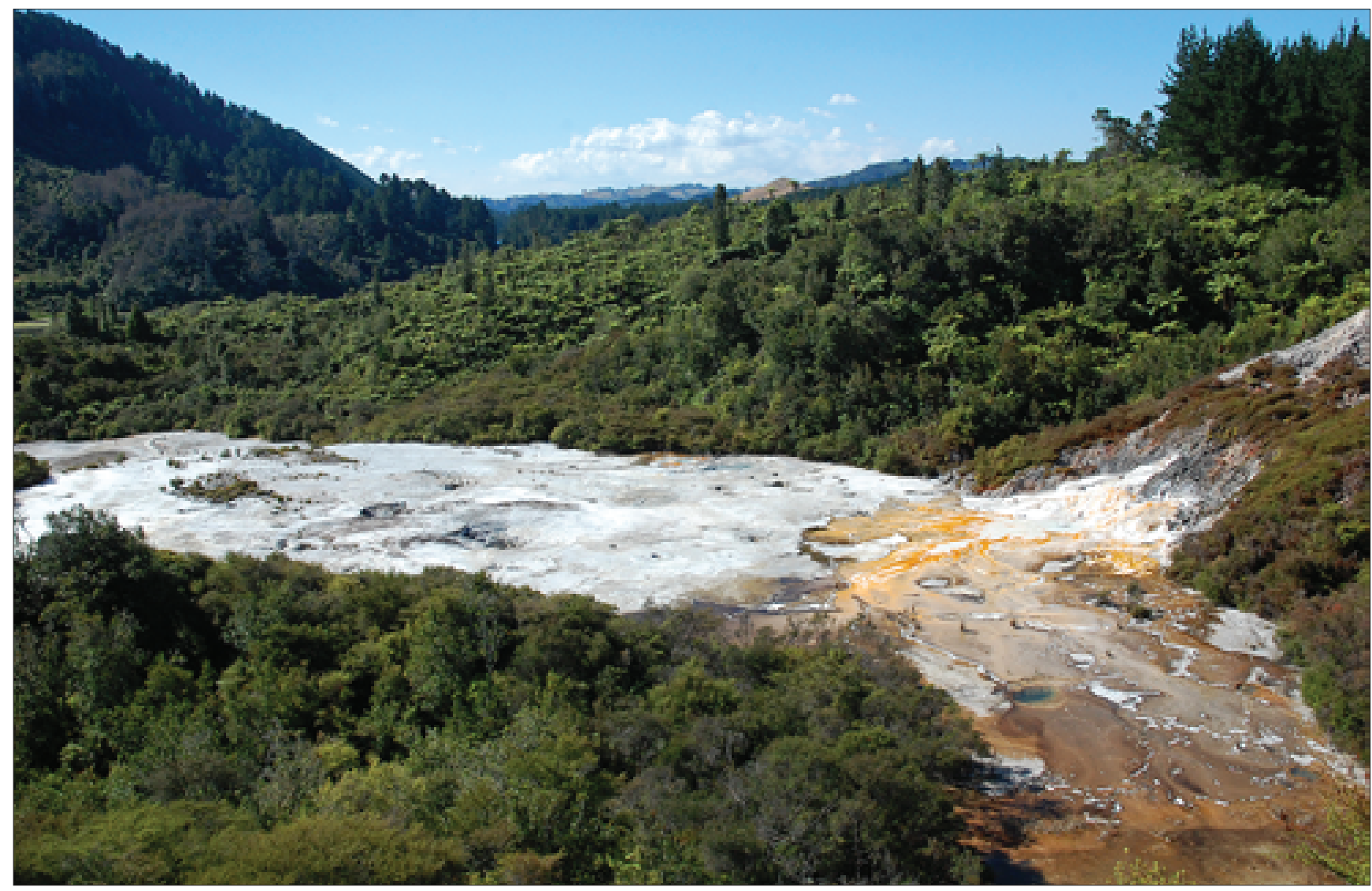

Fig. 14. Overview of Orakei Korako property, with elongated deposition zone of silica, photo P. Migoń • Ogólny widok stanowiska Orakei Korako z wydłużoną strefą akumulacji krzemionki, fot. P. Migoń 


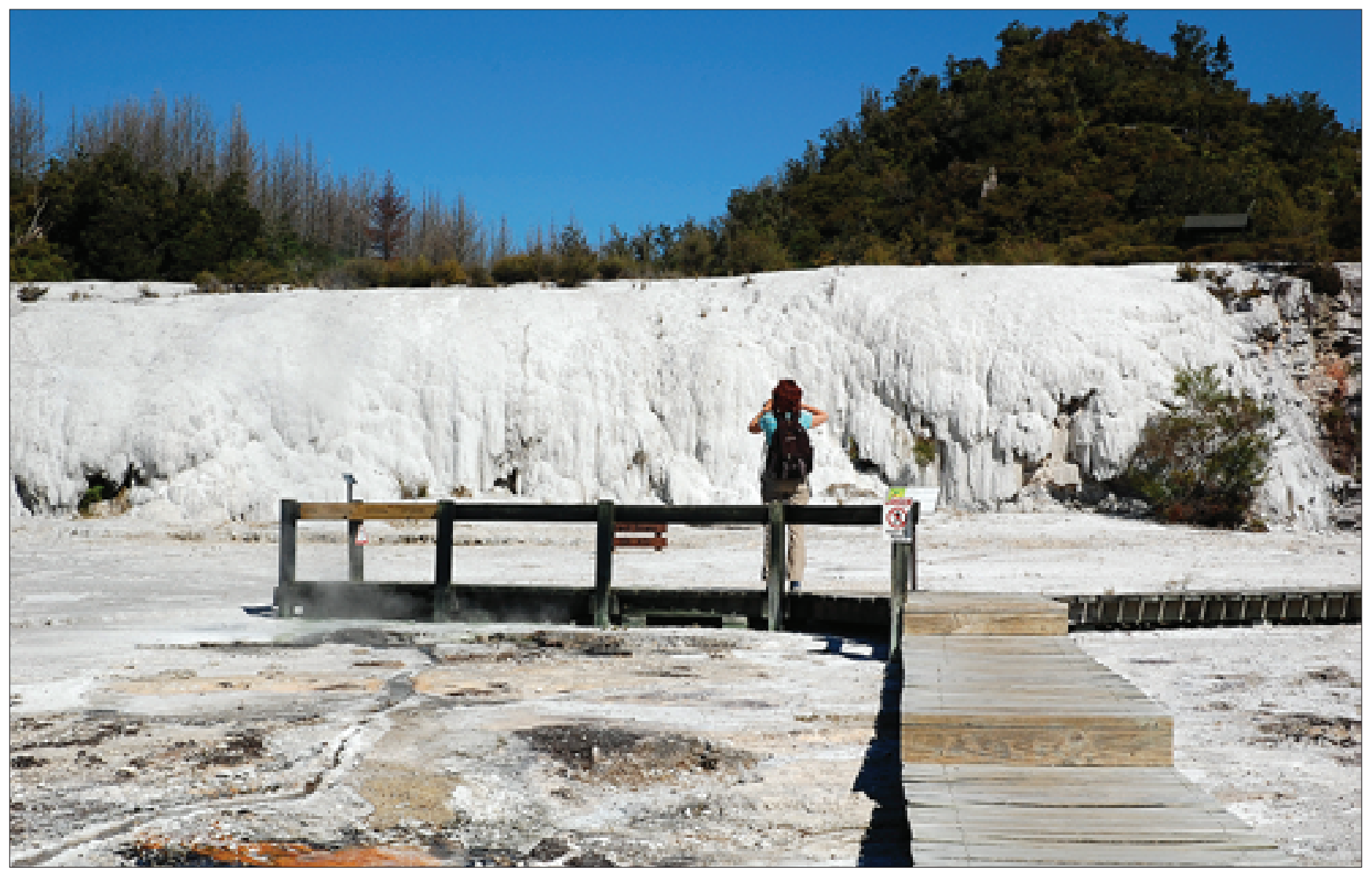

Fig. 15. Silica-covered fault scarp, Orakei Korako Geothermal Park, photo P. Migoń • Skarpa uskokowa pokryta krzemionką wytrąconą z wód hydrotermalnych Orakei Korako Geothermal Park, fot. P. Migoń

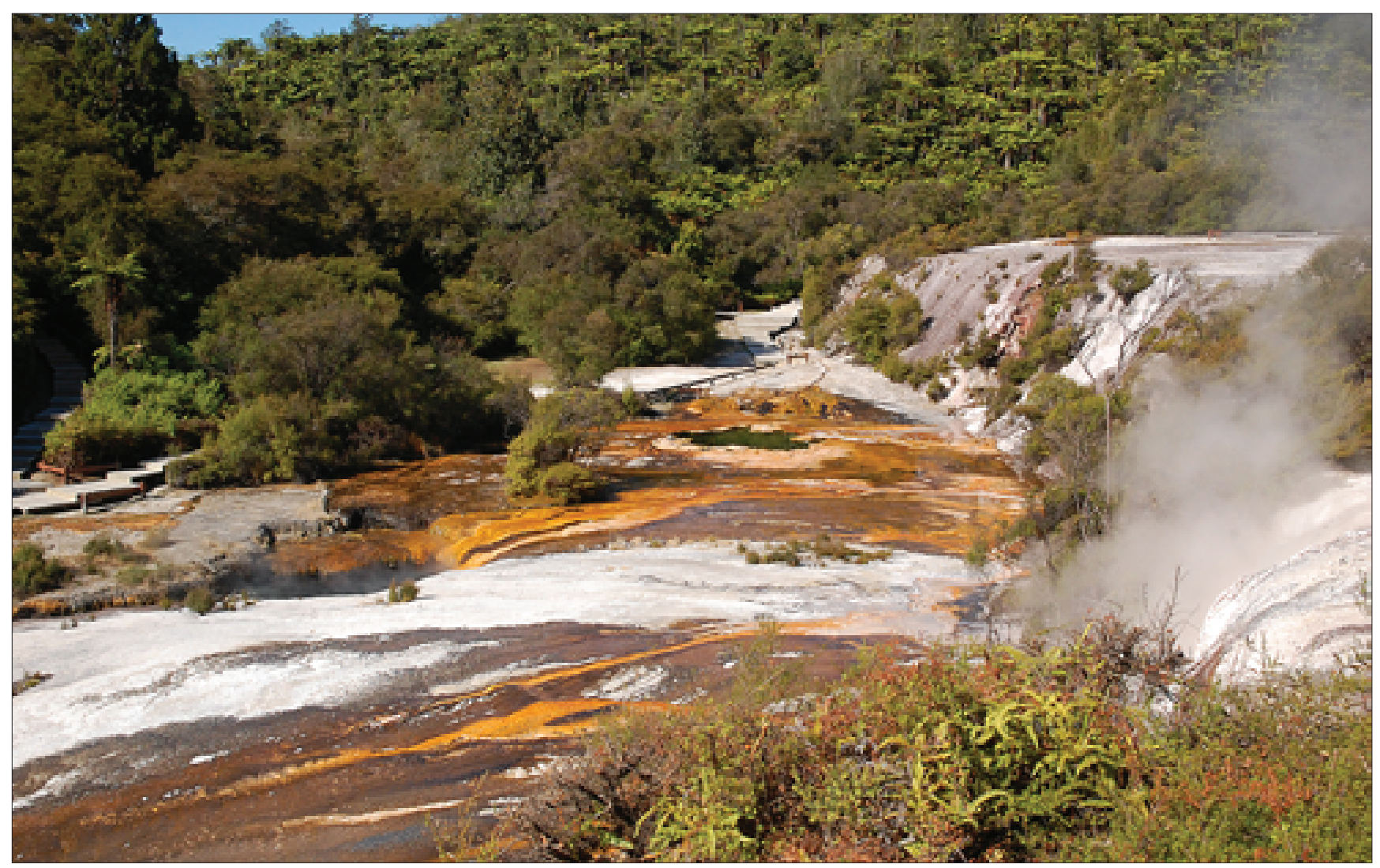

Fig. 16. Silica deposits, hot springs and fumaroles at Orakei Korako, photo P. Migoń • Depozycja krzemionki, gorące źródła i fumarole w Orakei Korako, fot. P. Migoń 


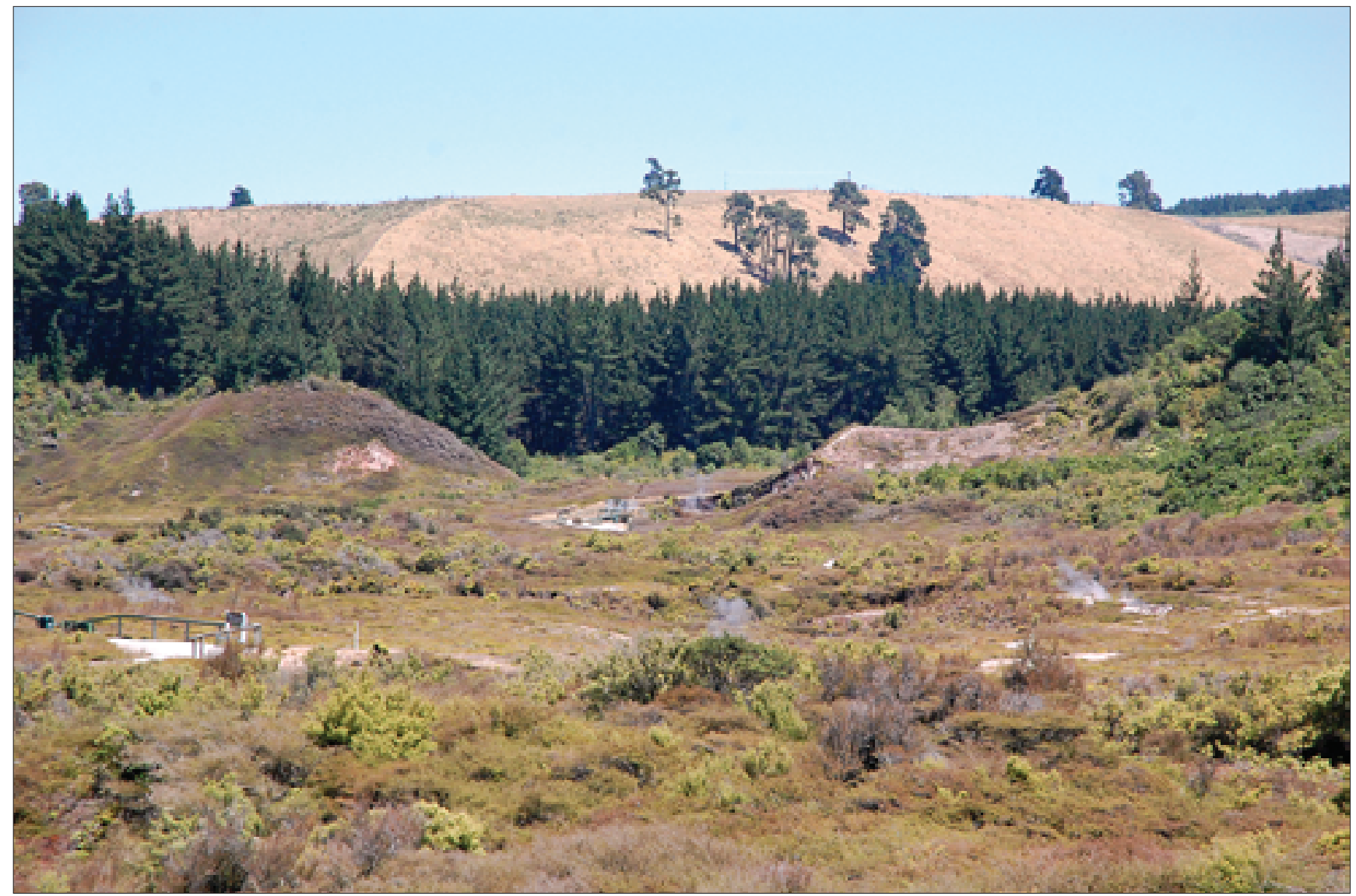

Fig. 17. Craters of the Moon - panoramic view, photo P. Migoń • Panoramiczny widok Craters of the Moon, fot. P. Migoń

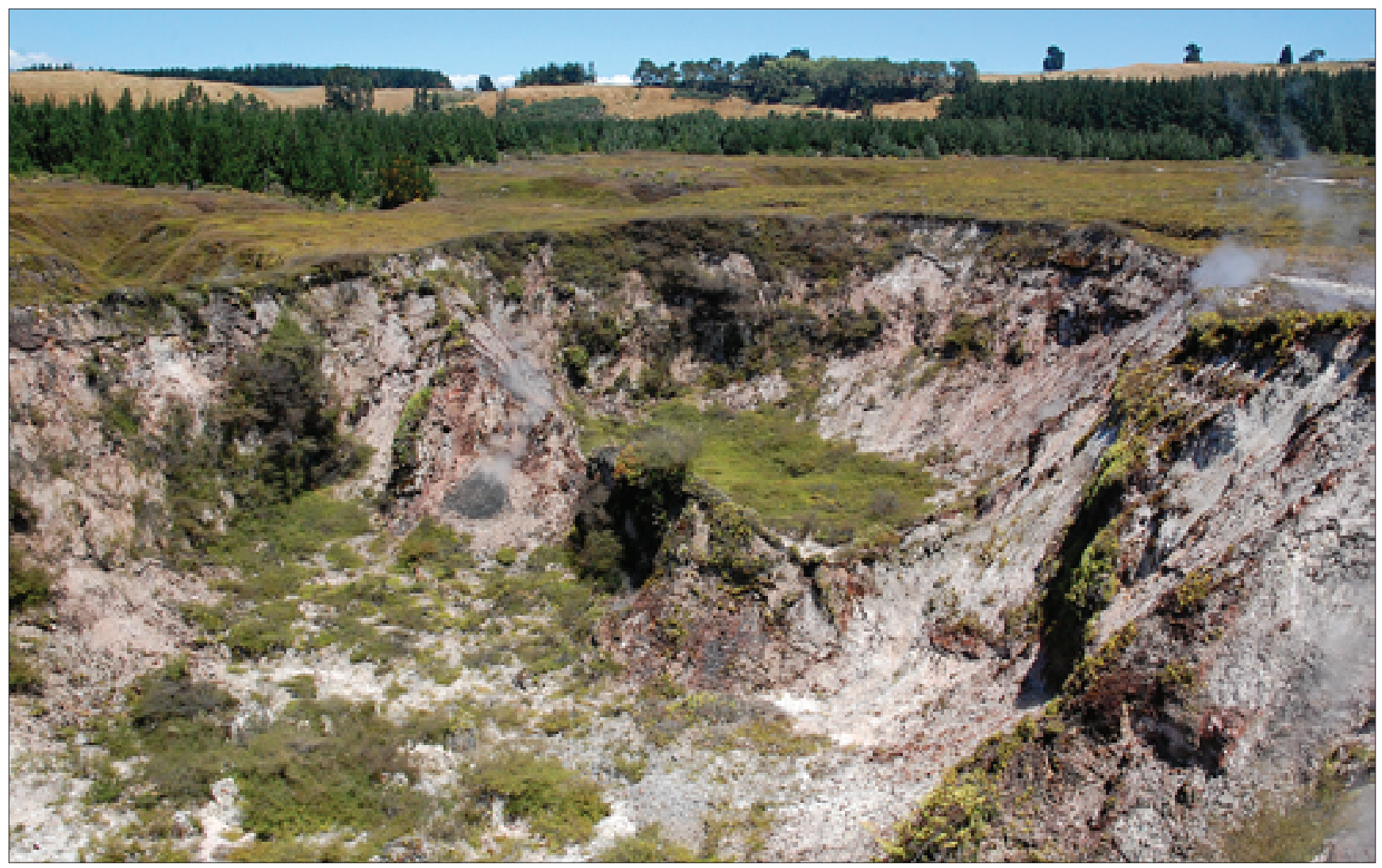

Fig. 18. One of collapse craters in the Craters of the Moon property, photo P. Migoń • Jeden z kraterów zapadliskowych w obszarze Craters of the Moon, fot. P. Migoń 


\section{Accessibility}

All geothermal sites presented in this paper are open to visitors practically the whole year round, with longer opening hours in summer (Tab. 1). Being located within a maximum 30-45 minute drive from the tourist centres in Rotorua or Taupo, they can be easily reached by car. However, only Te Puia, located in the outskirts of Rotorua, is accessible by city bus. To all places, except Craters of the Moon, shuttle bus connections or organized trips by travel agencies are also offered.

The range of entrance fees is quite significant, from the lowest price ( 8 NZD) in Craters of the Moon to the most expensive Te Puia (51 NZD). The other three sites are within a very similar price range. The visits are intended as self-guided, but in Te Puia, Waimangu Volcanic Valley and Wai-O-Tapu guided tours are also offered for an extra fee. Only Te Puia and Craters of the Moon are accessible for tourists with disabilities in wheelchairs. In Waimangu a free shuttle bus connects the two ends of the site, located nearly $4 \mathrm{~km}$ apart. At all sites tourist facilities include information stands, souvenir shops, cafes, or food and beverages kiosks.

The minimum time required for the visit is from $45 \mathrm{~min}$ utes in Craters of the Moon to at least 2 hours for the visit to Waimangu Volcanic Valley. The latter visit, if combined with the cruise of Lake Rotomahana (paid extra), may last half a day. In all places maps show the main and optional walking trails, along with short descriptions of the most interesting sites.
Access to geothermal touristic sites must to satisfy two requirements: to allow maximum experience among the visitors and ensure their safety while visiting a hazardous environment, with unstable ground, elevated temperatures and the likelihood of violent events such as hot water eruptions or ground collapses. At all properties considered here wooden boardwalks are used extensively (Fig. 19) and they serve three purposes. Besides limiting contact with unstable bedrock, they constrict tourist flows and help conservation of fragile and dynamic geothermal landforms. However, fencing is sporadically used, for the benefits of scenic values of the sites. It is apparently assumed that understanding and awareness is sufficient among the visitors so that they obey simple warning signs and do not venture beyond marked trails and wooden walkways (Fig. 20).

\section{Visitor-oriented promotional tools}

\section{Identifiers in printed materials and websites}

An intention to demonstrate distinctiveness in relation to other sites in the vicinity, all based upon an apparently similar set of natural phenomena, is evident at each geothermal property considered in this paper. Identifiers used in their destination marketing strategies include advertising slogans, logos, photographs of the most representative geothermal features, and other symbols.

Tab. 1. Summary of accessibility at geothermal sites considered in this paper • Dostępność obiektów geotermalnych opisanych w artykule

\begin{tabular}{|c|c|c|c|c|c|}
\hline Accessibility & Te Puia & Waimangu & Wai-O-Tapu & Orakei Korako & $\begin{array}{l}\text { Craters of } \\
\text { the Moon }\end{array}$ \\
\hline opening hours & $\begin{array}{c}8.00-18.00 \\
\text { (summer) } \\
8.00-17.00 \text { (winter) }\end{array}$ & $\begin{array}{l}\text { 8.30-16.40 (last ad- } \\
\text { mission - summer) } \\
\text { 8.30-15.40 (winter) }\end{array}$ & $\begin{array}{c}8.30-17.00 \text { (summer) } \\
8.30-15.40 \text { (winter) }\end{array}$ & $\begin{array}{c}\text { 8.00-17.30 } \\
\text { (summer) } \\
\text { 8.00-16.30 (winter) }\end{array}$ & $\begin{array}{c}\text { 8.00-18.00 } \\
\text { (summer) } \\
\text { 8.00-17.30 (winter) }\end{array}$ \\
\hline $\begin{array}{l}\text { duration } \\
\text { of walks }\end{array}$ & minimum 1.5 hour & $\begin{array}{l}\text { minimum } 2 \text { hours } \\
\text { (one way) }\end{array}$ & $\begin{array}{c}\text { walks: } 1.5 \mathrm{~km}, \\
2 \mathrm{~km}, 3 \mathrm{~km} \text { (from } \\
30 \text { to } 75 \text { minutes) }\end{array}$ & minimum 1 hour & $\begin{array}{l}\text { minimum } \\
45 \text { minutes }\end{array}$ \\
\hline $\begin{array}{l}\text { admission fee } \\
\text { (as of Decem- } \\
\text { ber 2015) }\end{array}$ & $\begin{array}{l}51 \text { NZD (standard } \\
\text { admission, without } \\
\text { Maori cultural show) }\end{array}$ & 37 NZD & $32.50 \mathrm{NZD}$ & NZD & $8 \mathrm{NZD}$ \\
\hline facilities on site & $\begin{array}{l}\text { shop, cafe, } \\
\text { restaurant }\end{array}$ & $\begin{array}{l}\text { information centre, } \\
\text { shop, cafe }\end{array}$ & $\begin{array}{c}\text { information centre, } \\
\text { shop, cafe }\end{array}$ & $\begin{array}{l}\text { shop, cafe, infor- } \\
\text { mation centre }\end{array}$ & $\begin{array}{l}\text { souvenir stand, } \\
\text { information point }\end{array}$ \\
\hline $\begin{array}{l}\text { availability of } \\
\text { guided tours }\end{array}$ & yes & $\begin{array}{l}\text { yes: half day or full } \\
\text { day (with cruise) }\end{array}$ & $\begin{array}{c}\text { yes: } \\
4 \text { hour or } 8 \text { hour tours }\end{array}$ & no & no \\
\hline $\begin{array}{l}\text { distance } \\
\text { from towns }\end{array}$ & $\begin{array}{l}\text { in Rotorua, } 3 \mathrm{~km} \\
\text { from the city centre }\end{array}$ & 24 km from Rotorua & $\begin{array}{l}27 \text { km from Rotorua, } \\
50 \text { km from Taupo }\end{array}$ & $\begin{array}{c}36 \mathrm{~km} \text { from Taupo, } \\
70 \mathrm{~km} \text { from } \\
\text { Rotorua }\end{array}$ & $\begin{array}{l}4 \mathrm{~km} \text { north } \\
\text { of Taupo }\end{array}$ \\
\hline $\begin{array}{l}\text { handicap } \\
\text { access }\end{array}$ & yes & very limited & $\begin{array}{l}\text { limited } \\
\text { (only the en- } \\
\text { trance loop) }\end{array}$ & no & yes \\
\hline $\begin{array}{l}\text { access by pub- } \\
\text { lic transport }\end{array}$ & $\begin{array}{l}\text { city bus from } \\
\text { Rotorua }\end{array}$ & $\begin{array}{l}\text { shuttle bus or guid- } \\
\text { ed tour from Rotorua }\end{array}$ & $\begin{array}{l}\text { shuttle bus from } \\
\text { Rotorua }\end{array}$ & $\begin{array}{l}\text { shuttle bus } \\
\text { from Taupo }\end{array}$ & not available \\
\hline
\end{tabular}




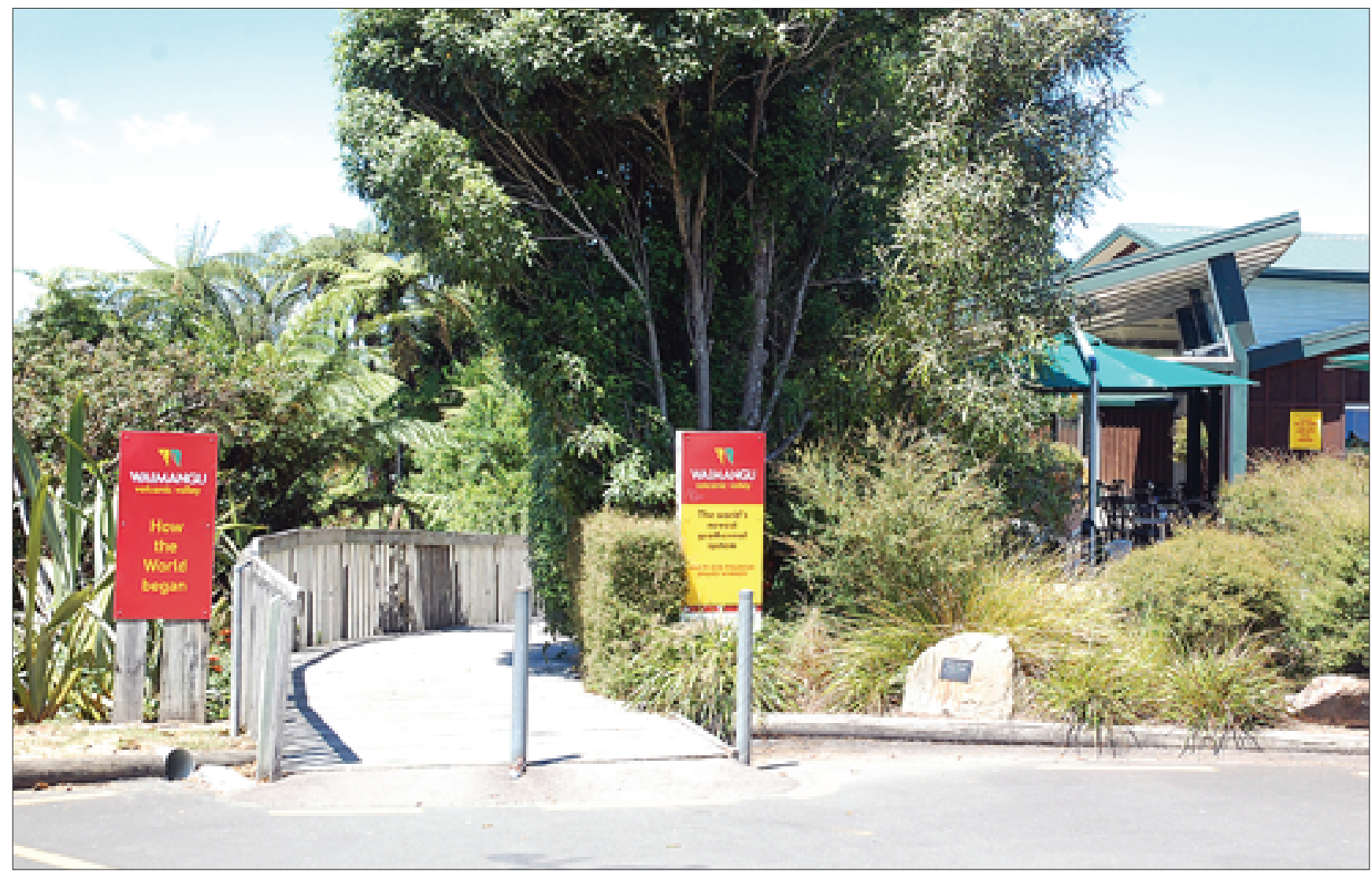

Fig. 19. Entrance to Waimangu Volcanic Valleys, with advertising slogans emphasizing very young age of volcanic and geothermal phenomena, photo P. Migoń - Wejście do wulkanicznej doliny Waimangu, z hasłami reklamowymi podkreślającymi bardzo młody wiek zjawisk wulkanicznych i geotermalnych, fot. P. Migoń

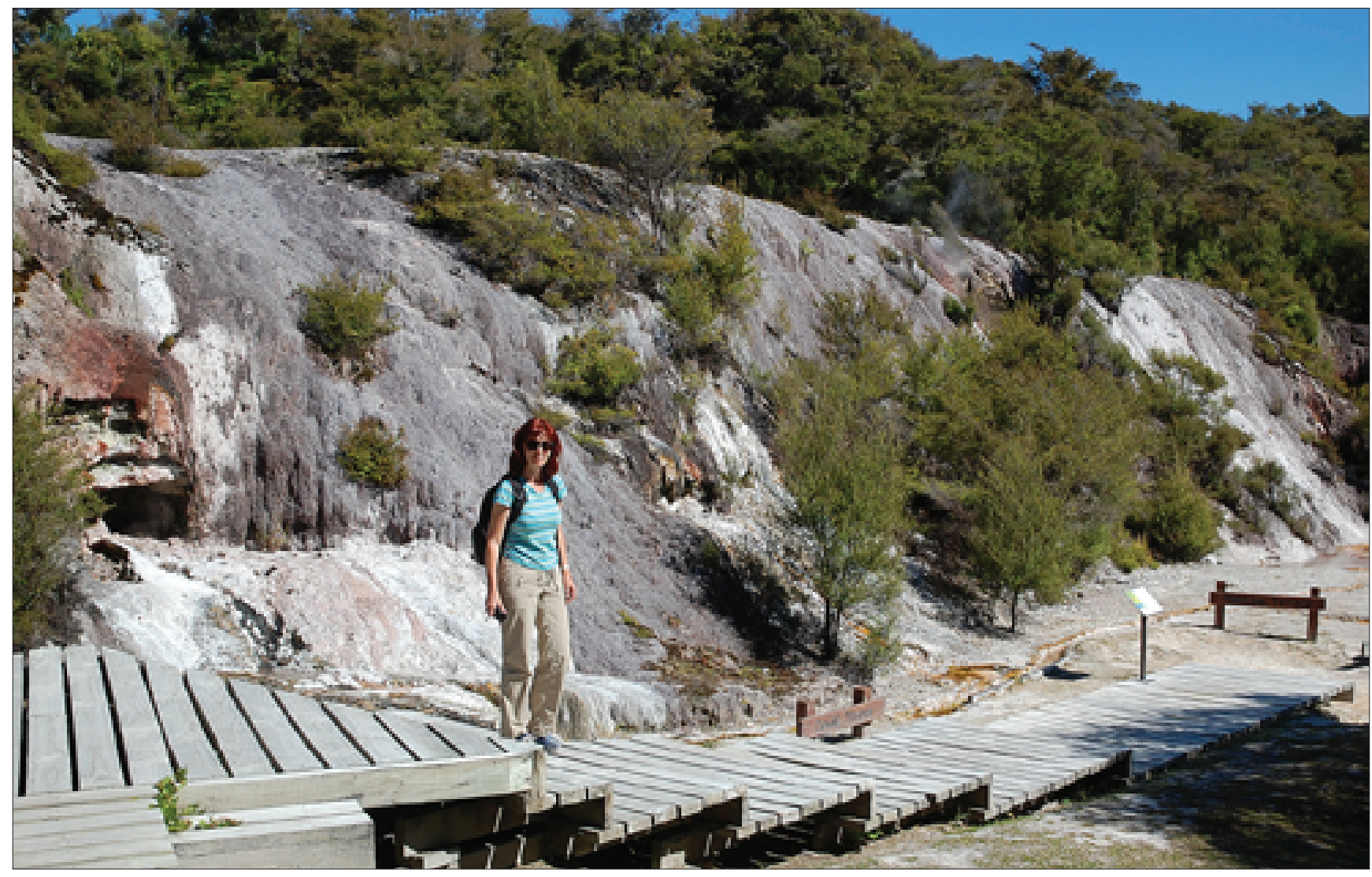

Fig. 20. Wooden boardwalks at Orakei Korako, photo P. Migoń • Drewniane pomosty dla odwiedzających w Orakei Korako, fot. P. Migoń 


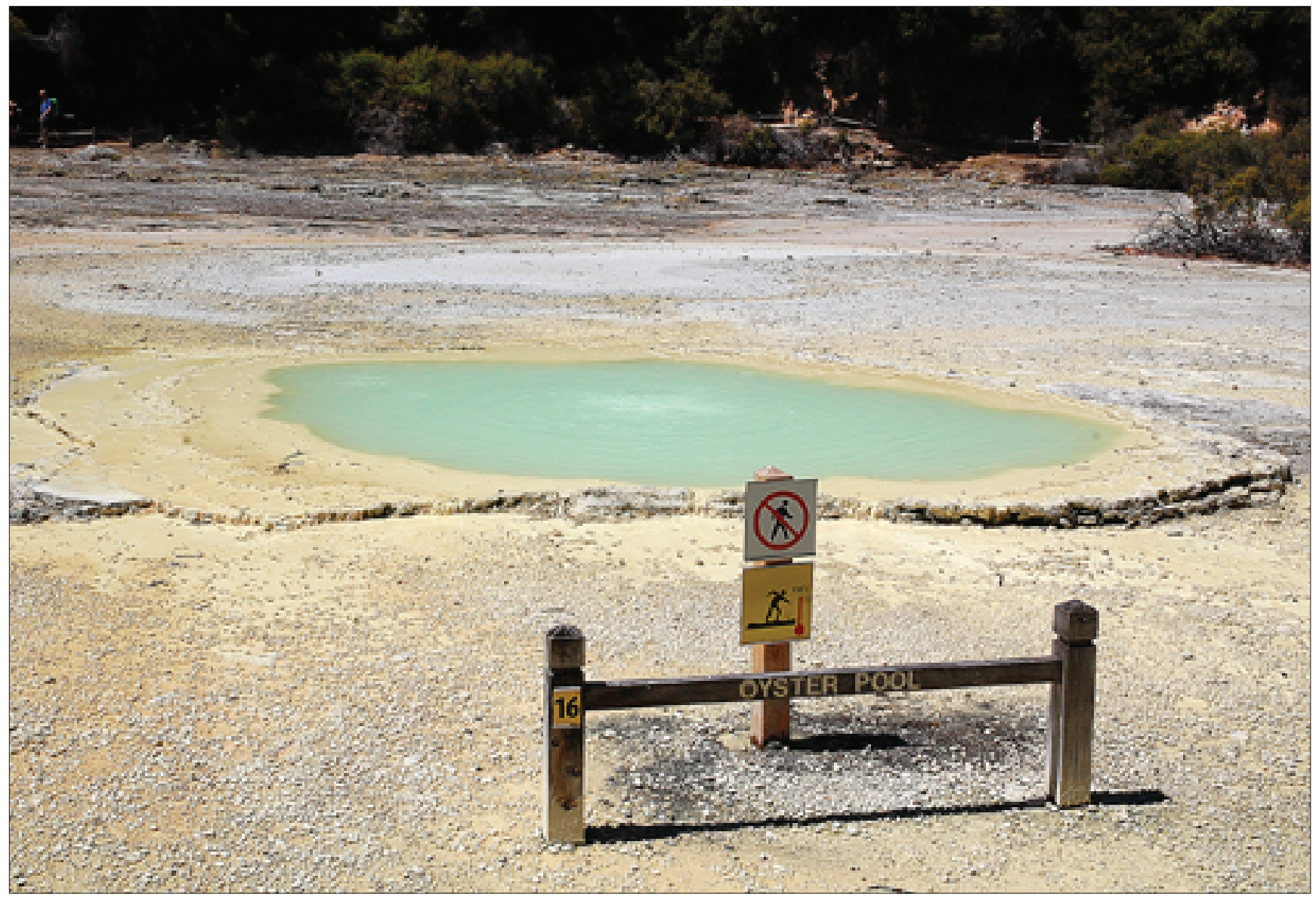

Fig. 21. Simple warning signs for tourists, Wai-O-Tapu, photo P. Migoń • Proste graficzne ostrzeżenia dla turystów, Wai-O-Tapu, fot. P. Migoń

At Te Puia Whakarewarewa an opportunity to become acquainted with Maori culture and everyday life, both strongly linked to geothermal phenomena, is emphasized. This is shown by the advertising slogan "New Zealand's premier Maori centre and home of the world famous Pohutu Geyser" used in promotional leaflets and on website. In each promotional material Maori symbols, particularly elaborate carvings, are presented jointly with geothermal features, mainly spectacular geyser eruptions. In fact, the Living Maori Village Whakarewarewa uses a very similar combination of symbols.

Promotion of Waimangu Volcanic Valley is much more nature-oriented, with the emphasis on sustainable tourism. The property is a member of Rotorua Sustainable Tourism Charter. Among indicators of this approach is the design of a trail brochure included in the admission fee, printed on lustreless paper, with limited use of colour. The key features of the site highlighted in the promotional materials are the very recent age of geothermal phenomena and relief in general, as well as diversity to be experienced at the property. The main advertising slogan reads 'The World's youngest geothermal area' (Fig. 21), whilst the focus on experiencing volcanic - geothermal history is evident in further catch phrases used in promotional materials such as 'Amazing Geothermal
Activity', 'Step into a World of wonderful geothermal features and beautiful volcanic creatures', and 'Nature that everyone can enjoy'.

Not surprisingly, natural geothermal phenomena are also emphasized at Wai-O-Tapu through phrases such as 'Unique volcanic wonders' and 'Explore spectacular nature', although the main slogan 'Thermal wonderland' - actually, part of the name of the property - seems to appeal to a different category of visitors than the more specific slogans at Waimangu. Consequently, colour is heavily used in printed and web-based materials, with photos of snow-white Lady Knox Geyser eruption and red-yellowish rims of the Champagne Pool being the repetitive theme.

A partially different strategy has been chosen by Orakei Korako, which uses the quotation from the Lonely Planet series guidebook that reads 'Orakei Korako - arguably the best thermal area left in New Zealand'. The intention to emphasize uniqueness is demonstrated by the slogan 'Cave and thermal park', even if only entrance to the cave can be viewed from the trail. As at Wai-O-Tapu, readers of brochures are exposed to the colourful scenes from the silica terraces which clearly decide about the recognition potential of the place. The property also offers a unique visitor experience in the form of a flight over the geothermal field. 
Craters of the Moon capitalize upon their name, using the slogan 'Geothermal walkway with lunar landscapes'. The main features presented within the property are highlighted through both the phrase 'Natural thermal activity. Bubbling craters, steam vents and mud pools' and photographs of steaming ground have been selected for brochures and the website. In terms of destination marketing, a unique feature of this particular site is an upfront information about low admission fees in contrast to other sites.

\section{Joint promotion and cooperation}

Available promotional materials do not contain any information suggesting that the geothermal sites considered here are involved in cooperative activities towards building a joint tourist product. Likewise, at none of the sites information about other properties, presented in a more elaborate way, can be found. By contrast, cooperation with other tourist attractions occurs, but the latter are clearly of a different kind. Thus, a package offer named 'Middle Earth Trilogy' is available that includes discounted admissions to Te Puia (geothermal site), Waitomo Glowworm Caves near Hamilton, and participation in Hobbiton Movie Set Tour. These three sites are considered 'star attractions' of the central part of the North Island, especially for foreign tourists. A more region-oriented 'Rotorua Trilogy' package combines Waimangu Volcanic Valley with Whakararewarewa - the Living Maori Village (in a way, competitor of Te Puia, located just next to it) and the Rotorua Museum, thus nature, local traditional lifestyle, and history, respectively. In the case of Craters of the Moon the proximity of the scenic Huka Falls on Waikato River is emphasized and a joint virtual guidebook to both these localities has been prepared. However, the Huka Falls are a free-access site. No comparable package offers are available in conjunction with either Wai-O-Tapu or Orakei Korako.

\section{Interpretation}

\section{Interpretation boards}

Each site considered here is equipped with interpretation boards placed along the walkways, but their number and depth of information vary (Fig. 22). There are two types of the panels, apparently serving two different purposes. Those at Waimangu, Wai-O-Tapu and Craters of the Moon offer more in-depth explanation, with textual explanation accompanied by photographs, diagrams, and maps. They are not necessarily related to the very spot where they have been erected. At Orakei Korako their purpose is to help in orientation, so that description is kept very simple, to a few lines, and the only graphic addition is its location highlighted against the entire trail. At Te Puia the purpose was similar and short text was carved in wooden boards, without diagrams to enrich the information. In addition, the panels have somehow faded away and the visibility of the text is often poor. No information board is present at Lady Knox Geyser but the site is only accessed once a day, when the eruption occurs, and the show is preceded by a brief explanatory talk from the warden.

Conceptually, the panels at Craters of the Moon appear best ordered, telling a story that starts from general explanation of geothermal phenomena (site 1), followed by more specific presentation of craters and fumaroles (site 2), relationship of people to geothermal sites (site 3), plant adaptations to excessive ground heat (site 4), terminated at a viewpoint overlooking the basis, where a wider picture of the Taupo Volcanic Zone is provided (site 5). Panels at Waimangu provide fairly comprehensive information too, but more focused on landforms and phenomena that can be seen from a given place.

Overall, given the length of the trails $(1.75-3.5 \mathrm{~km}$, except Te Puia which does not have one evident trail to follow) the number of interpretive boards can be considered rather low. However, at most sites visitors are presented with printed materials (leaflets, maps) which also contain descriptions of objects of interest along the trails, playing complementary role in interpretation.

\section{Printed materials}

In this section we only consider materials which are included in the admission price and are available to every visitor. In terms of content, the highest quality trail brochures are those at Waimangi and Wai-O-Tapu. The former, although rather dull in appearance, contains a description of 40 specific points along two trails within the reserve. The most interesting ones from the scientific and scenic point of view are explained in more detail, with diagrams to help understanding the life cycle of the Inferno Crater or the succession of volcanic materials in a road cut exposure. An informative sketch map is provided. The latter is printed in full colour on a glossy paper and contains a trail map and explanation what the visitor can observe at each of 25 points of interest. By contrast, materials provided at Te Puia and Craters of the Moon are essentially simple trail maps, with very limited explanation and interpretation. In fact, among 13 points of interest contained in the Te Puia leaflet only two are geothermal phenomena. No special explanatory trail brochure is offered at Orakei Korako.

\section{How to learn more?}

Interpretation offered at basic level by means of trail boards and leaflets is ideally supplemented by a more comprehensive presentation of geothermal phenomena in dedicated books and maps, as well as in specially designed exhibitions at visitor centres. However, all sites considered here have very little to offer in this respect. None of the gateways to the sites feature an educational exhibition focused on volcanism, geothermal phenomena, or more broadly on geoscience. Likewise, shops sell mostly souvenirs and do not have popular science books on sale. Only the shop at Waimangu has a limited offer that includes an interesting collection of free 1-page pamphlets detailing past eruptions, entitled 'Eruption chronicles', no. 1 to 6. 

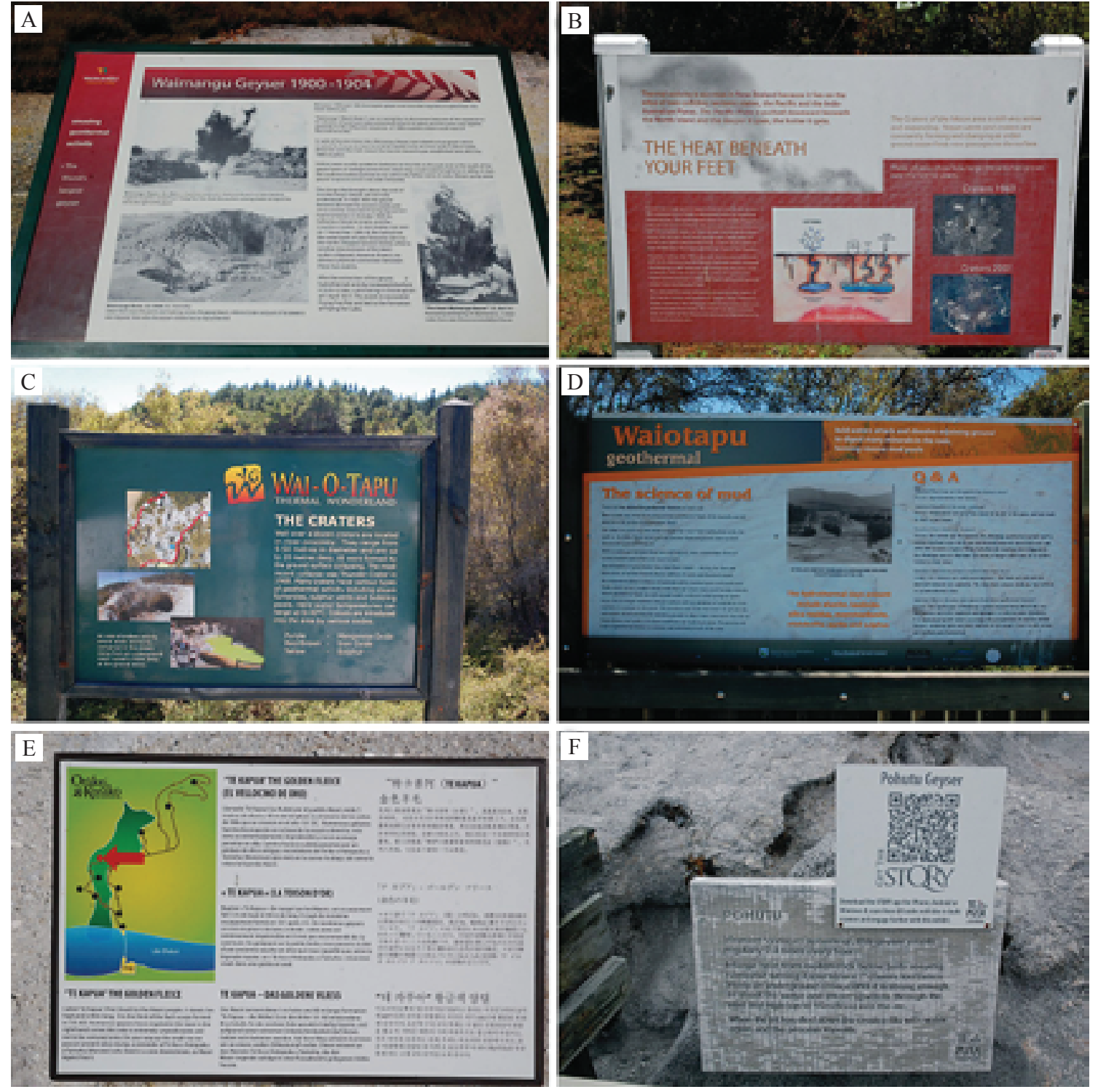

Fig. 22. Examples of information/interpretation boards from different geothermal sites. A - elaborate and informative panel in Waimangu Volcanic Valley, detailing history of Waimangu Geyser; B - panel at Craters of the Moon introduces diversity of geothermal phenomena, at the site and in general; C - explanation of crater origin, Wai-O-Tapu; D - informative panel at Mud Pool, Wai-O-Tapu; E - multilingual but otherwise very simple information board at Orakei Korako - one of more than ten scattered across the property; F - simple and least attractive information panel about Pohutu Geyser at Te Puia, all photos P. Migoń - Przykłady tablic informacyjnych z różnych obiektów geotermalnych Nowej Zelandii. A - obszerna treściowo tablica z wulkanicznej doliny Waimangu prezentująca historię gejzeru Waimangu; B - tablica w Craters of the Moon wprowadzająca w problematykę różnorodności zjawisk geotermalnych w odniesieniu do obiektu i ogólnie; C - wyjaśnienie genezy kraterów, Wai-O-Tapu; D - tablica informacyjna przy Mud Pool, Wai-O-Tapu; E - wielojęzyczna, bardzo prosta pod względem graficzno-treściowym tablica informacyjna w Orakei Korako - jedna z kilkunastu umieszczonych wzdłuż ścieżki; F - prosta i niezbyt atrakcyjna tablica informacyjna przy gejzerze Pohutu w Te Puia, wszystkie fotografie P. Migoń

Likewise, websites are marginally used to enhance learning experience and very little scientific or popular science content is available. 'Geothermal Valley' bookmark in Te Puia website does contain photographs of all features of geoscientific interest accompanied by short descriptions, but only two of them - geysers and mud pools - are explained in more detail. No general explanation of geothermal phenomena is provided by either Waimangu, Wai-O-Tapu and Craters of the Moon websites, although individual landforms are briefly described. 'Waimangu News' is a bookmark to inform about recent research in the area, but communications are very brief. The most comprehensive information about geothermal phenomena is available via Orakei Korako website, with focus on two landforms distinctive for this property, i.e. sinter terraces and caves of geothermal origin. One can also learn about chemical processes involved and the role of microorganisms in colouring the mineral deposits.

Finally, Wai-O-Tapu - a member of Rotorua Educational Network - advertises educational activities which may be organized at the property, including geography lessons at different levels of formal education. However, these products are not available for an individual visitor. 


\section{Discussion}

\section{Are the sites different in terms of the main geothermal themes?}

Most geothermal features are common for all analysed properties. The only two really unique features are the $\mathrm{Ru}-$ atapu cave at Orakei Korako and the mud volcano cone at Te Puia, but neither is presented as the main highlight of the site. Volcanic craters at Waimangu can also be considered unique, but as a group, not individually. Therefore, characteristics most emphasized in promotional activities are size and age, i.e. (a) silica terraces at Orakei Korako - 'the largest existing in New Zealand', (b) Champagne Pool at Wai-O-Tapu - the deepest hot lake, (c) Frying Pan Lake at Waimangu - the world's largest hot spring, (d) the entire suite of geothermal phenomena at Waimangu, including explosion craters - the youngest such system in New Zealand, (e) Pohutu Geyser at the Puia - the highest and not modified anthropogenically (in contrast to the artificial Lady Knox Geyser at Wai-O-Tapu). Reference is also made to unusual features which no longer exist: once the highest geyser in the world in Waimangu and the largest mud volcano in New Zealand at Wai-O-Tapu.

While world- or country records have long been used in tourism advertising campaigns, in nature-based tourism the quantity and clarity of various features is equally important. From this standpoint the following key characteristics of each site emerge:

- Te Puia Whakarewarewa - large assemblage of geysers, active and extinct, with a variety of related silica deposits;

- Waimangu - unique group of aligned volcanic craters from 1886, with associated hot springs in some of them.
It should be noted, however, that only two have their floors accessible;

- Wai-O-Tapu - a group of collapse craters and the most vigorously boiling mud pool;

- Orakei Korako - not only the total length of silica deposition is important, but also its tiered nature, with prominent scarps across the 'silica flow', and a multitude of colours, especially in the lower part of the site.

Craters of the Moon are the least diverse among the five and although there are fine collapse craters within the property, they surely rank less than features of similar origin at Wai-O-Tapu.

These, together with the highlights named above, are the topmost values of the properties, at least from geotourism viewpoint. It is evident that four 'large' sites are complementary and each brings an important component to the full appreciation of geothermal phenomena and to its better understanding. Their association with volcanism is best exposed at Waimangu, their destructive face - at Wai-O-Tapu, the role in creating land by massive deposition of silica - at Orakei Korako, and geyser activity - at Te Puia Whakarewarewa. However, if one looks for one site offering the highest diversity, this will be Wai-O-Tapu (including Lady Knox Geyser and mud pool).

\section{Perception among the public}

Examination of the popular Trip Advisor website containing visitors' opinions shows that rating of the geothermal sites in the area is generally very good and most visitors report satisfaction from the visit. Although opinions expressed via one particular website cannot be considered entirely representative, their large number (Tab. 2) makes them a useful source of infomation.

Tab. 2. Visitors' ratings of geothermal sites between Rotorua and Taupo, according to Trip Advisor website (as for 31 December 2015) • Ocena atrakcyjności turystycznej obiektów geotermalnych między Rotorua i Taupo przez odwiedzających, na podstawie danych ze strony internetowej Trip Advisor (stan na dzień 31 grudnia 2015)

\begin{tabular}{|c|c|c|c|c|c|c|c|c|c|c|c|}
\hline \multirow{3}{*}{$\begin{array}{l}\text { Geother- } \\
\text { mal site }\end{array}$} & \multirow{3}{*}{$\begin{array}{c}\text { Total } \\
\text { responses }\end{array}$} & \multicolumn{10}{|c|}{ Evaluation } \\
\hline & & \multicolumn{2}{|c|}{ Excellent } & \multicolumn{2}{|c|}{ Very good } & \multicolumn{2}{|c|}{ Average } & \multicolumn{2}{|l|}{ Poor } & \multicolumn{2}{|c|}{ Terrible } \\
\hline & & $\begin{array}{l}\text { Number of } \\
\text { responses }\end{array}$ & $\%$ & $\begin{array}{l}\text { Number of } \\
\text { responses }\end{array}$ & $\%$ & $\begin{array}{l}\text { Number of } \\
\text { responses }\end{array}$ & $\%$ & $\begin{array}{l}\text { Number of } \\
\text { responses }\end{array}$ & $\%$ & $\begin{array}{l}\text { Number of } \\
\text { responses }\end{array}$ & $\%$ \\
\hline $\begin{array}{c}\text { Te Puia } \\
\text { Whakare- } \\
\text { warewa }\end{array}$ & 1979 & 1015 & 51.3 & 667 & 33.7 & 211 & 10,6 & 56 & 2.8 & 30 & 1.7 \\
\hline Waimangu & 786 & 524 & 66.6 & 213 & 27.2 & 35 & 4.5 & 10 & 1.3 & 4 & 0.5 \\
\hline $\begin{array}{l}\text { Wai-O- } \\
\text { Tapu }\end{array}$ & 3386 & 2062 & 60.9 & 1063 & 31.4 & 207 & 6.1 & 45 & 1.3 & 9 & 0.3 \\
\hline $\begin{array}{l}\text { Orakei } \\
\text { Korako }\end{array}$ & 730 & 471 & 64.5 & 207 & 28.4 & 41 & 5.8 & 6 & 0.8 & 3 & 0.5 \\
\hline $\begin{array}{l}\text { Craters of } \\
\text { the Moon }\end{array}$ & 678 & 250 & 29.8 & 250 & 36.9 & 162 & 23.9 & 50 & 7.4 & 14 & 2 \\
\hline
\end{tabular}


Very little difference exists between three countryside locations: Waimangu, Wai-O-Tapu and Orakei Korako, despite a vast imbalance in the number of opinions. All three are highly appreciated, with the sum of 'excellent' and 'very good' ratings exceeding $90 \%$. Waimangu comes first, with $93.8 \%$; it also receives the highest number of 'excellent' ratings. In each case, the sum of 'poor' and 'terrible' is less than $2 \%$. The urban locality of Te Puia Whakarewarewa lags behind, with a little above $50 \%$ of 'excellent' ratings and $4.5 \%$ of low scores. Craters of the Moon receive the least favourable opinions but the examination of the opinions themselves clearly shows that many responding tourists had previously visited one of the other, more developed and more diverse sites, and their judgement was influenced by comparative analysis.

Interesting remarks can be found associated with low ratings for Te Puia, as they indicate that people compare the sites and judge them against one another:

'It is infinitely inferior to the beautiful Wai-O-Tapu, further down the road, which is cheaper, much bigger and enclaved in a spectacular natural site'

'Do you want to look at geysers and geothermal features? Well, the nearby Wai-o-Tapu and Waimangu have much more interesting views'

'The Te Puia thermal area offers less to see than a site such a Waiotapu'

However, even Waimangu occasionally receives unfavourable comments, again based on a judgment that there are better (i.e. more diverse) sites nearby:

'having been to many thermal parks over the years I found it underwhelming and very expensive for what it is. There are a number of different things to see and do, but you can sum it up as "steam and trees»"

It remains an open question whether deficits in interpretation, particularly at Te Puia, has a significant bearing on the low ratings and the above opinions.

\section{Evaluating interpretation}

Despite some unfavourable comments, there is no doubt that all geothermal sites are very scenic and provide highly unusual or even unique experience of 'living Earth' for first-time visitors. However, they use this capital to develop geo-interpretation and to build educational programmes with variable intensity. Waimangu and Wai-O-Tapu clearly surpass the other properties, with trail brochures being their very strong assets. They are followed by Craters of the Moon, which - although perhaps least impressive among the five - has a finely crafted set of interpretation boards telling a coherent story. The other two sites exploit mainly aesthetic values of geothermal landforms and phenomena, offering limited interpretation both on boards and in leaflets. Interestingly, arguably the most famous and also the most expensive site to visit - Te Puia - is one where geoscientific explanation on the site is clearly neglected, despite the presence of the Pohutu Geyser on the premises.
Using the typology of tourists visiting sites of geological interest as a framework (Grant, 2010, after Dowling, 2011), we can evaluate the level of interpretation from this standpoint. This typology includes six categories: 'geo-expert', 'geo-specialist', 'geo-amateur', 'interested visitor', 'aware visitor' and 'unaware visitor', assuming decreasing a priori knowledge of phenomena to be seen. Waimagu and Wai-OTapu provide experience 'beyond the level of mere aesthetic appreciation' (Hose, 1995) and can also satisfy visitors up to the category of 'geo-specialist'. Craters of the Moon offer a useful introduction to the subject and since are located most to the south, can serve as a good starting point of a longer visit. Visits to Orakei Korako and especially Te Puia would require some knowledge in advance if more than aesthetic appreciation is to be experienced.

Differences between the sites are indirectly highlighted by choices of promotional catchwords. However, on site experience will likely vary, again depending on the antecedent familiarity with subject. Since each property has the repetitive set of the main phenomena, their products may look repetitive for 'unaware', but also 'aware visitors'. On the other hand, specialists and experts will clearly see the differences and are likely to consider the sites as complementary rather than subtle variations on one theme. This might provide an opportunity to create a joint geotourist product, in which the geothermal story can be developed. However, given that such visitors are few, competition rather than cooperation between sites may be expected.

The main weakness at the regional scale is very limited catering for those interested in more in-depth understanding of geothermal phenomena. There is 'Volcanic Activity Centre' near Taupo which combines a small, but very informative and interactive exhibition (Fig. 23) with a well-stocked bookshop with geological literature, but it is not heavily advertised and the distance from Rotorua is rather substantial. In conclusion, the sites analysed in this paper perform differently as 'geotourist destinations', none to the full satisfaction of 'specialists' and 'experts' (although Waimangu is close), and there is still room for improvement, especially at Te Puia in Rotorua which in a sense is a cradle of geothermal tourism in the region.

\section{Conclusions}

The main findings from this study are the following. First, visitors' experience is clearly directed towards scenic component (landscape, colour, smell, noise) and unique natural phenomena present at each site, including global records. Geo-education is much less developed and limited facilities exist to support it at the level of an individual visitor. This is particularly striking at Te Puia which is probably the most visited site. Few stories are told and information materials are restricted to identification and naming natural features, rather than being helpful in their understanding. Second, the sites are sufficiently diverse to offer distinctive educational products and complementary experience of the geothermal world. This might provide an opportunity to create a joint geotourist product, in which the comprehensive geothermal story can be developed. 




Fig. 23. Volcanic Discovery Centre near Taupo, photo P. Migoń - Ekspozycja w Volcanic Discovery Centre w pobliżu Taupo, fot. P. Migoń

Nevertheless, little if any cooperation exists amongst the different properties which apparently compete with each other on the tourist market. Rather, they tend to cooperate with properties offering cultural, thus very different kind of experience (museum, folk shows, adventure tourism). Third, all sites are adequately prepared to receive tourists in large quantities and on-site technical facilities are very well maintained. This is particularly important if one realizes hazards associated with geothermal phenomena.

To conclude, the geothermal sites offer first-class experience for senses, but there remains room for improvement of learning component at essentially each site. Whilst the geothermal properties are players on the competitive tourist market, better cooperation in geo-education is recommended, to enhance the understanding of geothermal phenomena which are among the best expressed globally.

\section{Acknowledgements}

Research stay of PM in New Zealand was organized within the EU-funded project 'Development of the potential and educational offer of the University of Wroctaw - the chance to enhance the competitiveness of the University'. We also extend our sincere thanks to Professor Mike Crozier and Sally Marx for their help and hospitality while in New Zealand.

\section{References (Literatura)}

Andrews P., 1995. Tarawera and the Terraces. Arrow Press, Morrinsville. Armiero V., Petrosino P., Lirer L., Alberico I., 2011. The GeoCaF project: proposal of a geosites network at Campi Flegrei (Southern Italy). Geoheritage, 3: 195-219.

Browne P.R.L., Lawless J.V., 2001. Characteristics of hydrothermal eruptions, with examples from New Zealand and elsewhere. Earth-Science Reviews, 5: 299-331.

Cody A.D., Lumb J.T., 1992. Changes in thermal activity in the Rotorua geothermal field. Geothermics, 21: 215-230.

Conly G., 1985. Tarawera. The Destruction of the Pink and White Terraces. Grantham House, Wellington.

Dowling R.K., 2011. Geotourism's global growth. Geoheritage, 3: 1-13.
Ell G., 1986. Discover New Zealand: Volcanic Places. The Bush Press, Auckland.

Ell G., 1995. Rotorua. Past and Present. The Bush Press, Auckland.

Erfurt-Cooper P., 2010. Introduction. In: Erfurt-Cooper P., Cooper M. (eds), Volcano and geothermal tourism: Sustainable geo-resources for leisure and recreation. Earthscan, London: 3-31.

Erfurt-Cooper P., 2011. Geotourism in volcanic and geothermal environments: playing with fire? Geoheritage, 3: 187-193.

Erfurt-Cooper P. (ed.), 2014. Volcanic Tourist Destinations. Springer, Heidelberg.

Grant C., 2010. Towards a typology of visitors to geosites. Paper presented at the Second Global Geotourism Conference, Making Unique Landforms Understandable. Mulu, Sarawak, Malaysia, 17-20 April (cited after Dowling, 2011). 
Hall C.M., Kearsley G.W., 2001. Tourism in New Zealand: an introduction. Oxford University Press, Melbourne.

Hall C.M., Lew A.A., 2009. Understanding and managing tourism impact. An integrated approach. Routledge, London - New York.

Houghton B., Scott B., 2008. Geyserland. A guide to the volcanoes and geothermal areas of Rotorua. Geological Society of New Zealand, Guidebook No. 13.

Hose T.A., 1995. Selling the story of Britain's stone. Environmental Interpretation, 10(2): 16-17.

Hunt T.M., Glover R.B., Wood C.P., 1994. Waimangu, Waiotapu, and Waikite geothermal systems, New Zealand: background and history. Geothermics, 23: 379-400.

Latocha A., 2006. Atrakcje geoturystyczne Nowej Zelandii. Geoturystyka, 3 (6): $3-14$

Lloyd E.T., 1959. The hot springs and hydrothermal eruptions of Waiotapu. New Zealand Journal of Geology and Geophysics, 2: 141-176.

Lloyd E.T., 1972. Geology and Hot Springs of Orakeikorako. New Zealand Geological Survey Bulletin, 85.

Lloyd E.T., 1975. Geology of Whakarewarewa hot springs. NZ Department of Scientific and Industrial Research, Information Series, No. 11.

McClure M., 2004. The Wonder Country. Making New Zealand Tourism. Auckland University Press, Auckland.

Neilson G., Bignall G., Bradshaw D., 2010. Whakarewarewa a Living Thermal Village - Rotorua, New Zealand. In: Proceedings World Geothermal Congress 2010. Bali, Indonesia, 25-29 April 2010: 1-7.
Newhall C., 2014. A dilemma for tourists and land managers alike: what risks to take? In: Erfurt-Cooper P. (ed.), Volcanic Tourist Destinations. Springer, Berlin - Heidelberg: 351-353.

Pearce D.G., Tan R., 2006. The distribution mix for tourism attractions in Rotorua, New Zealand. Journal of Travel Research, 44: 250-258.

Rodgers K.A., Hamlin K.A., Browne P.R.L., Campbell K.A., Martin R., 2000. The steam condensate alteration mineralogy of Ruatapu cave, Orakei Korako geothermal field, Taupo Volcanic Zone, New Zealand. Mineralogical Magazine, 64: 125-142.

Roscoe R., 2010. Geothermal parks in New Zealand. In: Erfurt-Cooper P. Cooper M. (eds), Volcano and geothermal tourism: Sustainable geo-resources for leisure and recreation. Earthscan, London: 324-328.

Ryan C., Pike S., 2003. Maori-based tourism in Rotorua: perception of place by domestic visitors. Journal of Sustainable Tourism, 11: 307-321.

Scott B.J., Gordon D.A., Cody A.D., 2005. Recovery of Rotorua geothermal field, New Zealand: Progress, issues and consequences. Geothermics, 34: 161-185.

Simmons S.F., Browne P.R.L., Scott B.J., 2004. Field Trip 2. Geothermal Systems. In: Geological Society of New Zealand - New Zealand Geophysical Society, 26th New Zealand Geothermal Workshop 6th-9th December 2004. Geological Society of New Zealand Miscellaneous Publication 117B: 11-40.

Warbrick A., 1934. Adventures in Geyserland. Reed, Dunedin - Wellington. www.tripadvisor.com 